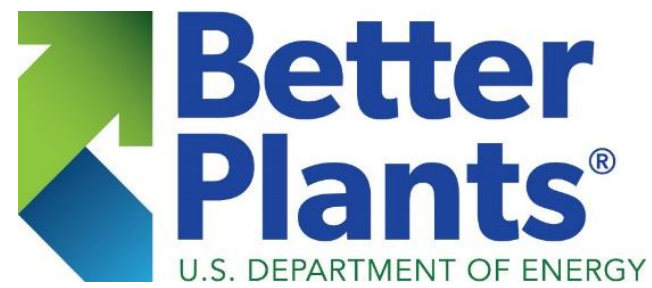

\title{
Understanding Your Utility Bills:
}
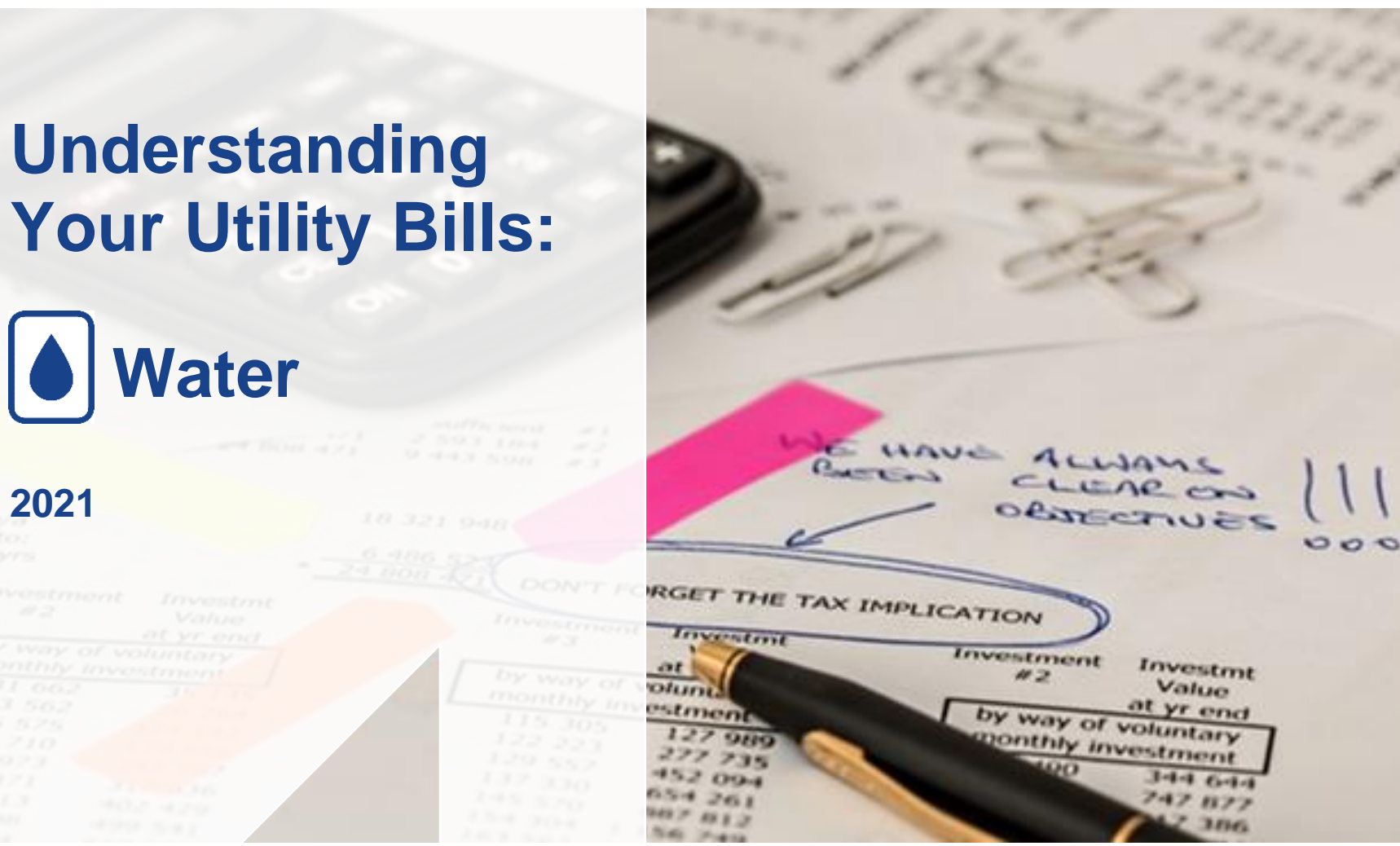


\section{Authors and Acknowledgements}

Understanding Your Utility Bills Guidance: Water was developed for the US Department of Energy's (DOE's) Office of Energy Efficiency and Renewable Energy as part of the Better Buildings, Better Plants program. The report was developed by staff at Oak Ridge National Laboratory in collaboration with the US Department of Energy. This report was funded by the Office of Energy Efficiency and Renewable Energy under Oak Ridge National Laboratory Contract No. DE-AC05-00OR22725.

The primary authors for this report are as follows:

Alexandra Botts, Manufacturing Science Division, Oak Ridge National Laboratory Christopher Price, Manufacturing Science Division, Oak Ridge National Laboratory Senthil Sundaramoorthy, Manufacturing Science Division, Oak Ridge National Laboratory Subodh Chaudhari, Manufacturing Science Division, Oak Ridge National Laboratory Thomas Wenning, Manufacturing Science Division, Oak Ridge National Laboratory

The efforts of the following contributors are appreciated for their review and suggestions to this guidance:

Sachin Nimbalkar, Manufacturing Science Division, Oak Ridge National Laboratory

Kiran Thirumaran, Manufacturing Science Division, Oak Ridge National Laboratory

Mini Malhotra, Buildings and Transportation Science Division, Oak Ridge National Laboratory

Eli Levine, Advanced Manufacturing Office, US Department of Energy

Bruce Lung, Boston Government Services LLC

Report Number: ORNL/SPR-2021/2083

Disclaimer: This report was prepared as an account of work sponsored by an agency of the United States Government. Neither the United States Government nor any agency thereof, nor any of their employees, makes any warranty, express or implied, or assumes any legal liability or responsibility for the accuracy, completeness, or usefulness of any information, apparatus, product, or process disclosed, or represents that its use would not infringe privately owned rights. Reference herein to any specific commercial product, process, or service by trade name, trademark, manufacturer, or otherwise, does not necessarily constitute or imply its endorsement, recommendation, or favoring by the United States Government or any agency thereof. The views and opinions of authors expressed herein do not necessarily state or reflect those of the United States Government or any agency thereof. 


\section{Preface}

The US Department of Energy's (DOE's) Better Buildings, Better Plants Program (Better Plants) is a voluntary energy, waste, and water efficiency leadership initiative for U.S. manufacturers and water/wastewater entities. The program encourages organizations to commit to reducing the energy intensity of their US operations over a 10-year period, typically by $25 \%$. Additionally, participants can commit to reducing their water or waste usage over the same 10year period with the Better Plants water savings initiative. To read more about the lessons learned from the DOE Better Buildings Challenge Water Savings Pilot, please refer to Developing a Corporate Water Management Strategy for Manufacturers ${ }^{1}$ on the Solutions Center website.

Companies joining Better Plants are recognized by DOE for their leadership in implementing energy and water efficiency practices and for reducing their usage. Better Plants Partners are assigned to a Technical Account Manager, who can help them establish water intensity baselines, develop water management plans, and identify key resources and incentives from $\mathrm{DOE}$, other federal agencies, states, utilities, and other organizations that can enable them to reach their goals.

Better Plants Partners are expected to report their progress to DOE once per year. This involves establishing a baseline upon joining the program and then tracking their progress over time. Understanding Your Utility Bills: Water is intended to help companies meet the program's reporting requirements by helping them to learn about and analyze their water and sewer bills. Data collected from utility bills can be used with the DOE Energy Performance Indicator software tool to establish an energy baseline and track progress over time.

This guidance document is applicable to companies participating at either the program or challenge level. Although this guide is intended primarily to assist companies participating in Better Plants, the methodologies and guidance within the document are applicable to any organization interested in understanding their water bills.

For more information on the Better Plants program, please visit betterbuildingssolutioncenter.energy.gov/better-plants

For more information on the Better Plants Challenge program, please visit https://betterbuildingssolutioncenter.energy.gov/better-plants/better-plants-challenge

${ }^{1}$ Rao, P., Developing a Corporate Water Management Strategy for Manufacturers (United States: Lawrence Berkeley National Laboratory, Berkeley, CA, April 2016), https://betterbuildingssolutioncenter.energy.gov/resources/corporate-water-management-strategy-manufacturers. 


\section{Contents}

Preface ... i

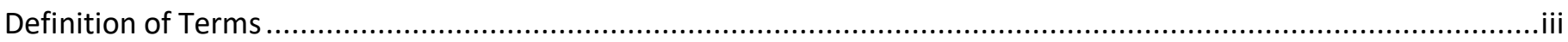

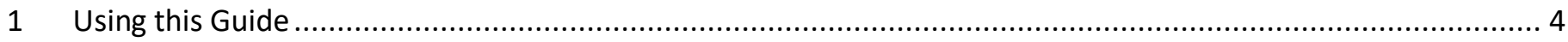

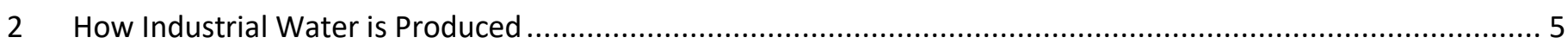

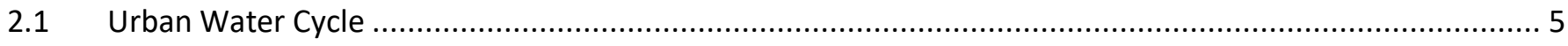

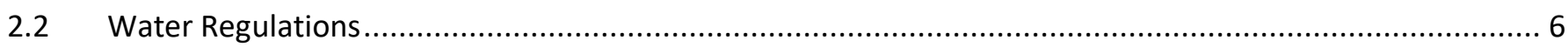

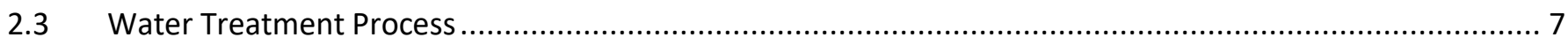

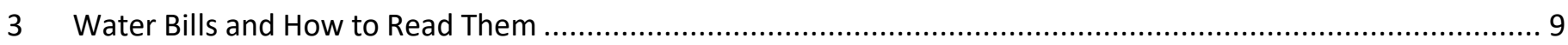

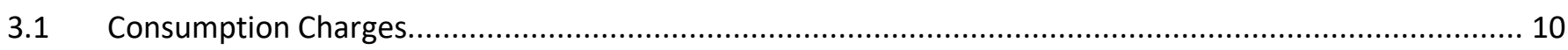

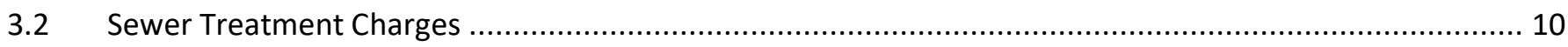

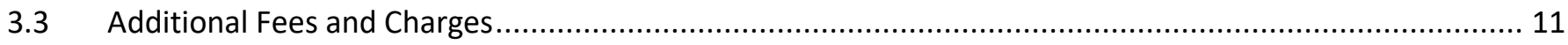

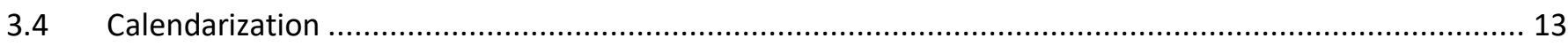

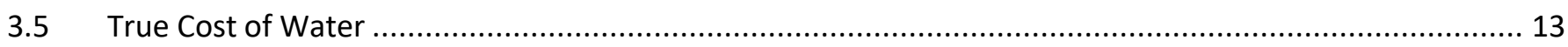

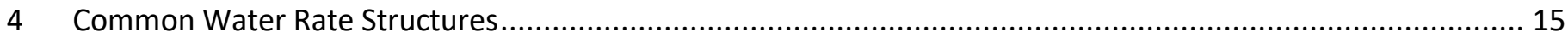

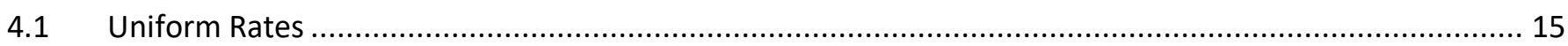

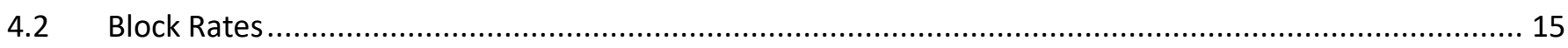

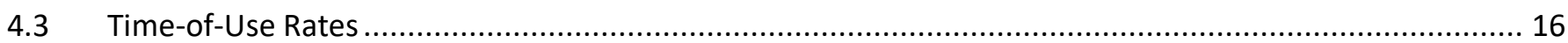

5 Saving Opportunities from Water Bill Analysis ............................................................................... 17

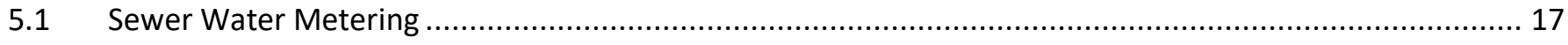

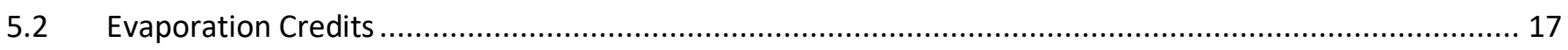

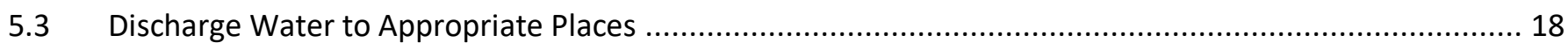

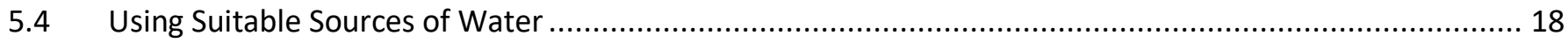

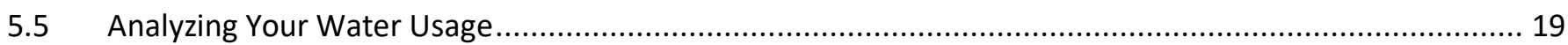

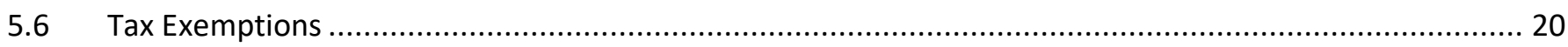

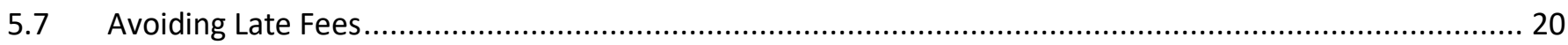

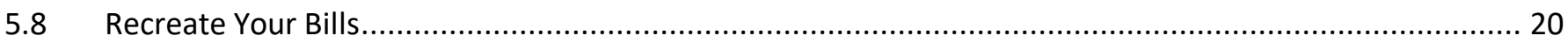

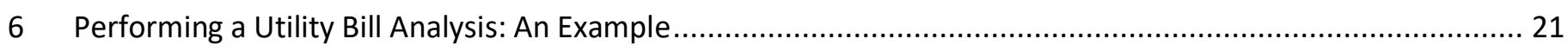

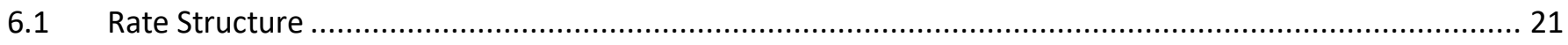

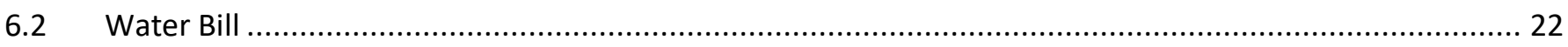

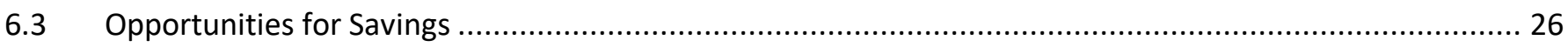

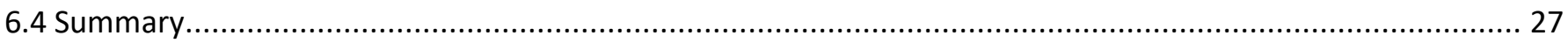

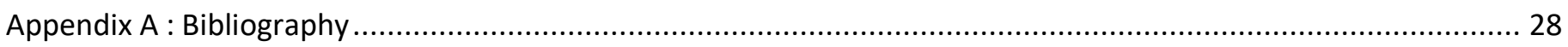

\section{List of Examples}

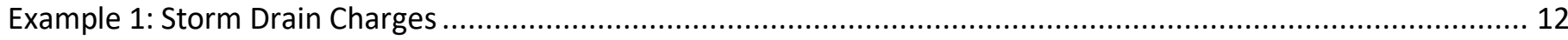

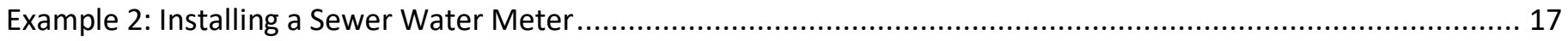

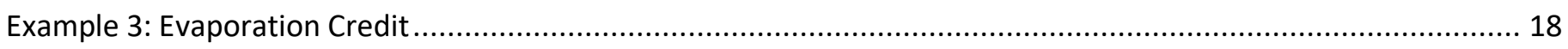




\section{Definition of Terms}

The following definitions apply to the Better Buildings, Better Plants Program. Certain terms may have different definitions in other methodologies or contexts.

Calendarization The process of allocating water usage and costs to standardized billing periods.

Predominant Use Study

A third-party analysis of water consumption on a water meter. If a certain percentage of usage is production related, some states offer exemptions on state sales tax.

Block Rates

Time-of-Use Rates

Uniform Rates

Riders

Sewer Charges

Sewer Treatment

Surcharge

Wastewater Treatment Facility

Water Treatment

Facility

Urban Water Cycle

Comfort Water

Influent Water

Potable Water

Process Water

Self-Supplied Water

True Cost of Water

Water Consumption

Effluent Water
A utility pricing structure in which the cost of water varies in steps based on the amount consumed.

A utility pricing structure in which the cost of water is higher during high-demand events.

A utility pricing structure in which the cost of water remains constant for all amounts of consumption.

Adjustments or changes to existing rate structures often used to finance regulatory requirements such as efficiency programs or environmental cleanup.

Charges directly related to the volume of discharged water that is sent to a wastewater treatment facility.

Additional charges for discharged sewer water with abnormal concentrations of containments.

A facility that physically and chemically treats dirty, raw water that has been discharged from end users before it is released to the environment as source water.

A facility that chemically and physically treats source water before distribution to end users.

The generalized cyclical process of collection, treatment, transportation, and distribution that water follows in urban environments.

Comfort water is non-value-added water that is not directly related to the process or final product. Examples include water used in restrooms or breakrooms.

Incoming water to a facility.

Water that is suitable for human consumption.

Water that is directly used in the manufacturing processes and that can be considered value-added to the final product.

Water drawn by the consumer from groundwater or surface-water sources.

The combination of indirect and directs costs associated with a facility's water use.

The volume of water measured by a water meter which is used to calculate charges on water bills. Common units include gallons and hundred cubic feet.

Exiting water from a facility. 


\section{Using this Guide}

Water and sewer bills can serve as a great source of information for cost reduction opportunities in a facility. Depending on your utility company, your bills can be very long and detailed or quite short, with just a few totals listed. Different charges can appear each month with no apparent explanation of why or how they are calculated. Learning to read your utility bills and understand why utilities charge different fees is important in maximizing your cost savings through water efficiency.

Partners in the US Department of Energy's (DOE's) Better Buildings, Better Plants (Better Plants) program are required to submit an annual energy report to DOE. However, the Better Plants program also offers an optional water-savings initiative for partners. The water-savings initiative takes a similar approach to the energy program in that partners establish a water intensity baseline. The first step in creating a baseline is collecting and analyzing several years of utility data. Historical metered data from your water and sewer bills can identify trends and help to find the best baseline year for your company. Utility data will also be used to document your progress in the Better Plants water-savings initiative, with the ultimate goal of achieving your water intensity improvement target and receiving recognition from DOE. Talk with your Better Plants Technical Account Manager (TAM) for more information about the water-savings initiative and how to join.

This document provides guidance on the basics of understanding industrial water and sewer bills (Figure 1). Section 2 provides an overview of how water is sourced, treated, supplied, and used in industrial manufacturing plants. Knowing how the water system is managed is key to understanding why utilities charge for consumption and sewer usage. While this guide focuses mainly on municipal water, other sources may be available to your facility. Section 3 gives an overview of the different types of charges on your bills, including consumption, sewer, and riders, and Section 4 discusses different rate structures your utilities might offer. Section 5 reviews water and sewer costsaving opportunities that you can identify simply by analyzing your utility bills. Finally, Section 6 provides a detailed example of how the concepts discussed in this guidance can be applied to a set of water and sewer bills.

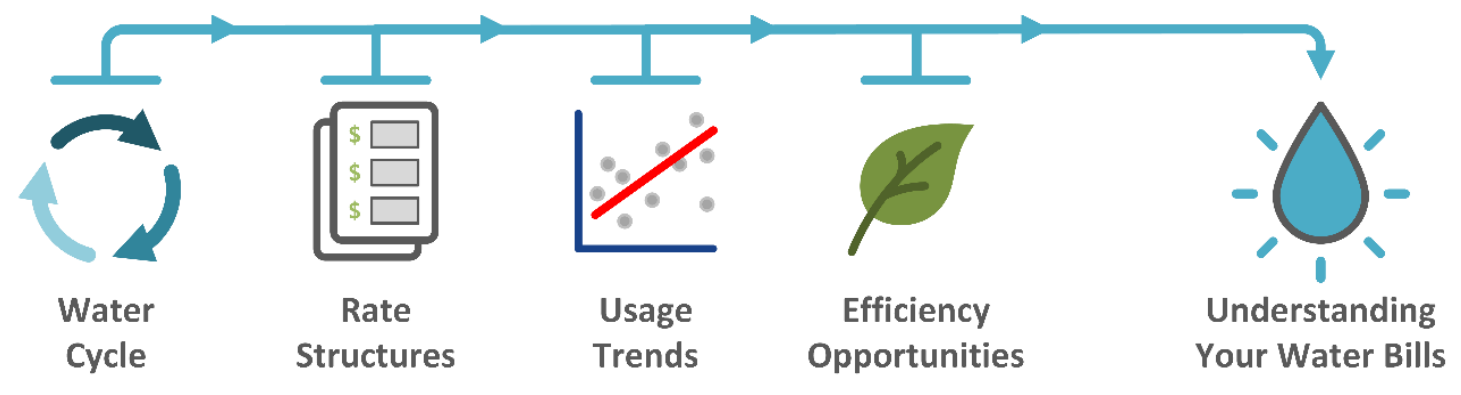

Figure 1: Key Aspects Needed to Fully Understand Your Water Bills.

This guidance is meant to cover topics that appear on most industrial water and sewer bills. However, each utility is different, and certain charges may be unique to your region. Utilities are also experimenting with new and innovative rate structures to encourage further water efficiency investments. Please contact your Better Plants TAM with any questions you might have about your bills or charges that might not be discussed in this document. 


\section{How Industrial Water is Produced}

The United States consumes roughly 400 billion gallons of water per day among industrial, agricultural, residential, and commercial users ${ }^{2}$. Industrial water accounts for $5-6 \%$ of the total US water consumption, or roughly 22 billion gallons of water per day. Industrial water can be drawn from a variety of sources, including self-supplied options such as ground or surface water, or from private or municipal suppliers. Of the water used by industrial consumers, $14 \%$ is sourced through a public system (Figure 2). When water is supplied or discharged to a public system, a billing structure is associated with the water. Understanding public water bills is valuable for facilities to encourage conservation measures and avoid unnecessary spending.

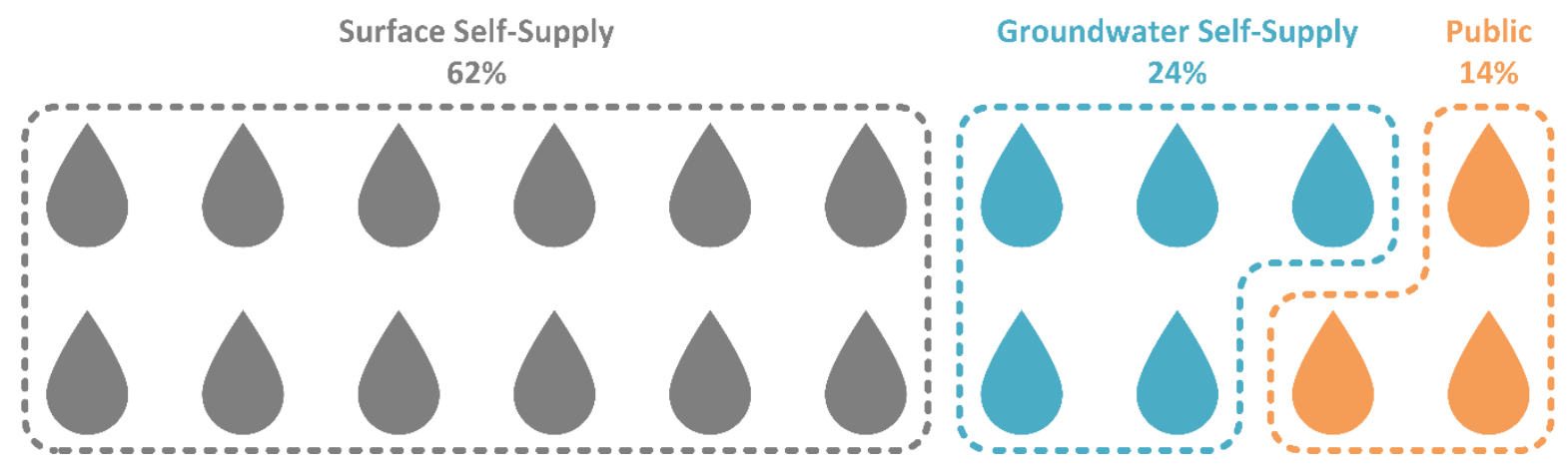

Figure 2: Sources of Industrial Water ${ }^{2}$.

In a manufacturing facility, water can be categorized into several types. For simplicity, this guide will divide water into process water and comfort water. Process water is directly related to the production of an end product. This could be any water considered value-added to the product, such as water used in steam production, rinsing or cooling of product, or water that is consumed to make the product itself. Comfort water is non-value-added water, such as in restrooms, HVAC systems for staff, kitchens, and water fountains. Comfort water is necessary for production but is not directly used in the manufacturing process.

This document focuses on utility-supplied water. Utility-supplied water is where most facility water or sewer bills will originate. Utility-supplied water includes water that is cleaned, treated, and transported by a utility company. The following section will describe the water treatment cycle and the origination of utility-sourced water.

\subsection{Urban Water Cycle}

Water is a vital resource used in a wide array of manufacturing processes. A vast majority of public water supplied to facilities is known as municipal water, meaning the water is treated and supplied by local infrastructure. Other facilities may independently treat their water or directly pull water from local sources; however, water will generally follow the same path. Unlike energy, water can be seen as a cyclical resource that is treated and reused repeatedly throughout the environment (Figure 3).

2 Dieter, C. A., Maupin, M. A., Caldwell, R. R., Harris, M. A., Ivahnenko, T. I., Lovelace, J. K., Barber, N. L., and Linsey, K. S., Estimated Use of Water in the United States in 2015, US Geological Survey Circular 1441, 65 p., 2018, https://doi.org/10.3133/cir1441. 


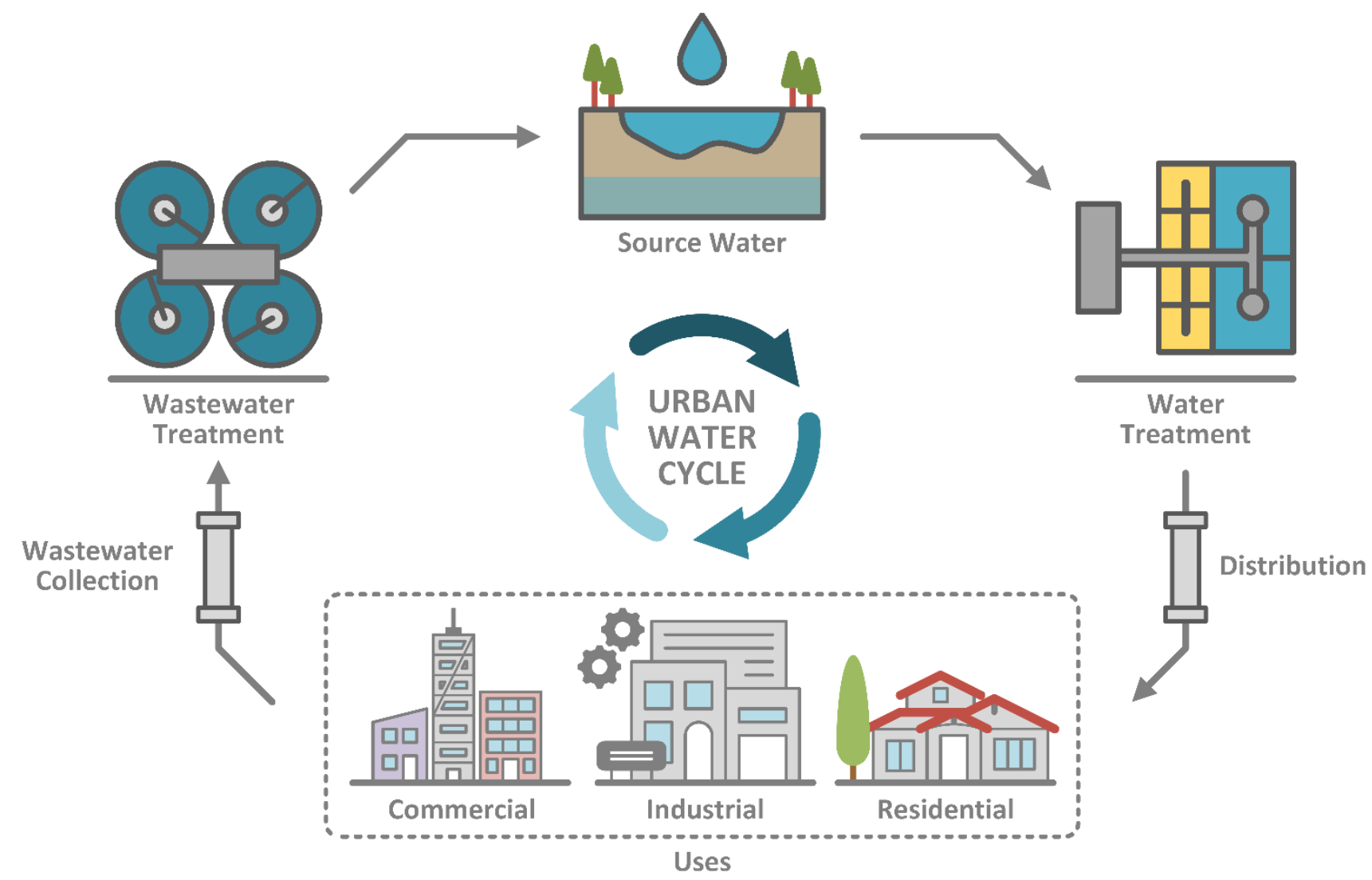

Figure 3: The Urban Water Cycle.

Water is pulled into water treatment facilities from local sources such as groundwater or rivers. Water treatment facilities physically and chemically treat the water to balance it to potable levels (i.e., safe for human consumption) by removing harmful substances and pathogens. Treated water is distributed through a system of pipes and pumps managed by your local utility for domestic and commercial use. After the point of use, the raw wastewater is collected via a sewer system and piped to a wastewater treatment facility where the raw water is treated to a level seen fit for environmental discharge back into the local sources. From this point, the urban water cycle begins again.

Depending on the operations at your facility, your water cycle might differ from this description. For example, some facilities can collect usable rainwater and skip the treatment and distribution steps. Some facilities may be required to treat their process water to remove contaminants from the manufacturing process before discharging it directly back into local water sources like rivers or lakes. Other facilities may even reuse part of their treated process water without discharging it at all. Thus, the urban water cycle is a general representation and not a one-size-fits-all description.

\subsection{Water Regulations}

The governing regulatory body for water quality in the United States is the US Environmental Protection Agency (EPA). More than 148,000 public water systems in the United States are regulated by the EPA annually ${ }^{3}$. These regulated public systems account for $90 \%$ of drinking water for all Americans. According to the EPA, a public water system can be publicly or privately owned, and the water systems are classified into three different types ${ }^{3}$ :

3 US Environmental Protection Agency. "Information about Public Water Systems," https://www.epa.gov/dwreginfo/information-aboutpublic-water-systems. 
- Community water system-A water system that supplies water to the same population year-round. These types of systems supply water to residential, industrial, and commercial users without their own water systems. This type of system is what most people think of as a public water system.

- Non-Transient Non-Community Water System-A public system that regularly supplies water to at least 25 of the same people at least six months per year. Examples include schools, hospitals, or factories that have their own water systems.

- Transient Non-Community Water System-A public water system that provides water in locations with temporary users. Examples include places such as a gas stations or campgrounds where people do not remain for long periods of time.

The systems mentioned above are examples of public systems that must follow drinking water standards and regulations set out by the EPA. Several regulations and laws surrounding water quality, chemical disposal, and conservation exist. The most notable legislation for manufacturers is the Safe Drinking Water Act (SDWA) of $1974^{4}$. The SDWA authorizes the EPA to protect the water quality in the United States by establishing minimum quality standards for public tap water. Amendments to the SDWA later required detailed risk and cost assessments and peer-reviewed science when developing these standards.

To monitor public systems, the EPA developed the Public Water System Supervision (PWSS) program ${ }^{5}$. This program is the primary means of ensuring federal compliance with the SWDA. The program ensures SWDA adherence by testing and analyzing samples from water treatment sites. Reports are drafted from these results for water system stakeholders and legislators to make informed decisions regarding the water quality and take corrective action if needed.

\subsection{Water Treatment Process}

Water quality should always be a top priority for consumers. Whether the water is used in manufacturing processes or for comfort water consumed by employees, the condition of the water can affect product quality, health, safety, and the environment. Geographical location and the unique particulates in your local water will determine how your water is processed. In general, water treatment follows the same four steps: coagulation and flocculation, sedimentation, filtration, and disinfection, ${ }^{6}$ as seen in Figure 4 and described below:

1. Coagulation and flocculation-This method is more commonly seen in water treatment than wastewater treatment. Positively charged chemicals are added to the incoming water and debris, neutralizing the negatively charged particles and dirt and causing them to bind with each other and form larger clumps, called floc.

2. Sedimentation-Due to the increased weight, floc will settle to the bottom of the supply, forming a layer of sediment.

3. Filtration-Once the floc has settled, the remaining clear water is routed through a filtration system. Several filtration systems are used in the industry, and they vary in composition and pore sizes. Common filtration systems include activated carbon, reverse osmosis membrane, or mixed media (sand, gravel, and charcoal) or a combination of methods. The goal of a filtration system is to remove dissolved and suspended particles (bacteria, dust, and chemicals) from the water.

\footnotetext{
4 US Environmental Protection Agency. "Summary of the Safe Drinking Water Act," https://www.epa.gov/laws-regulations/summary-safedrinking-water-act.

5 US Environmental Protection Agency. "Safe Drinking Water Act (SDWA) Compliance Monitoring," https://www.epa.gov/compliance/safedrinking-water-act-sdwa-compliance-monitoring.

${ }^{6}$ Centers for Disease Control and Prevention. Drinking Water, "Water Treatment," https://www.cdc.gov/healthywater/drinking/public/water_diseases.html.
} 
4. Disinfection -At this point, chemicals (such as chlorine or chloramine) or ultraviolet lights can be used to remove any remaining impurities and help protect the treated water from germs during distribution to end users.

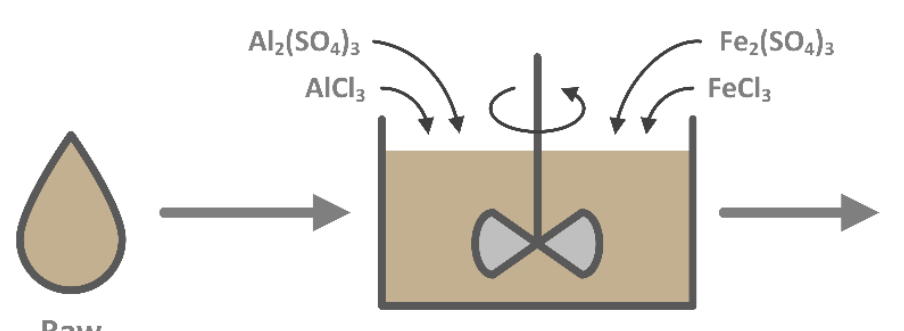

Raw

Water
Coagulation

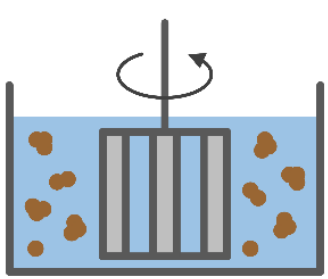

Flocculation

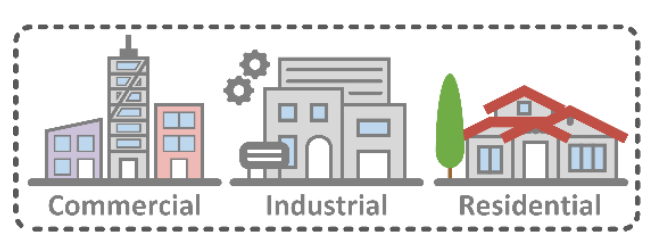

End Users

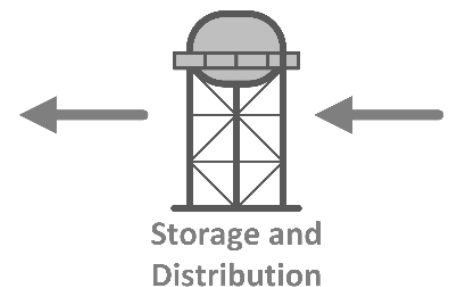

Distribution

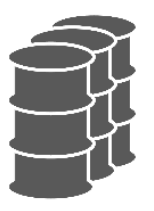

Water Treatment

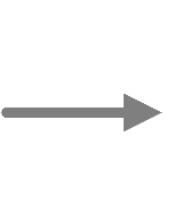

Sedimentation

Figure 4: Water Treatment Process.

These four steps are applied to both the wastewater treatment and water treatment process, as depicted in the urban water cycle shown in Figure 3. Wastewater treatment and water treatment go through the same general process except wastewater treatment is more rigorous. The methods used at your local water treatment facility can have a direct effect on your water and sewer bills. If the chosen method requires more maintenance or has a higher capital cost, a direct cause for higher water prices in your area will exist. 


\section{Water Bills and How to Read Them}

To understand your water bill, you first have to know how you are being charged and why. Water bills are usually fairly similar from region to region, but there may be a few slight differences. To get a full list and a comprehensive breakdown of charges, you can look up your local tariff or rate structure on your utility's website. The tariff will outline all the charges on the bill as well as how they are calculated. Facilities are encouraged to review their tariff annually because tariffs are updated and changed regularly.

Similar to electric bills, water can be provided through several different entities. Your water bill can come from either a private or public organization. Public water systems are run by the embodied government, such as the city or county. Private water sources are independently owned and operated by private companies that have been deemed a utility. A facility may also have two or more water bills, typically split between water costs and sewer costs being paid to two different parties. Regardless of who controls the treatment facilities or the infrastructure, water bills are generally organized with similar charges.

Figure 5 shows an example water bill. Common information found on water bills include the meter number, consumption reading, consumption charges, sewer charges, various fees, and taxes. The following sections will provide an overview of these key aspects of a water bill. Understanding what these charges cover and why they are assessed is key in avoiding or reducing their impact on your bills.

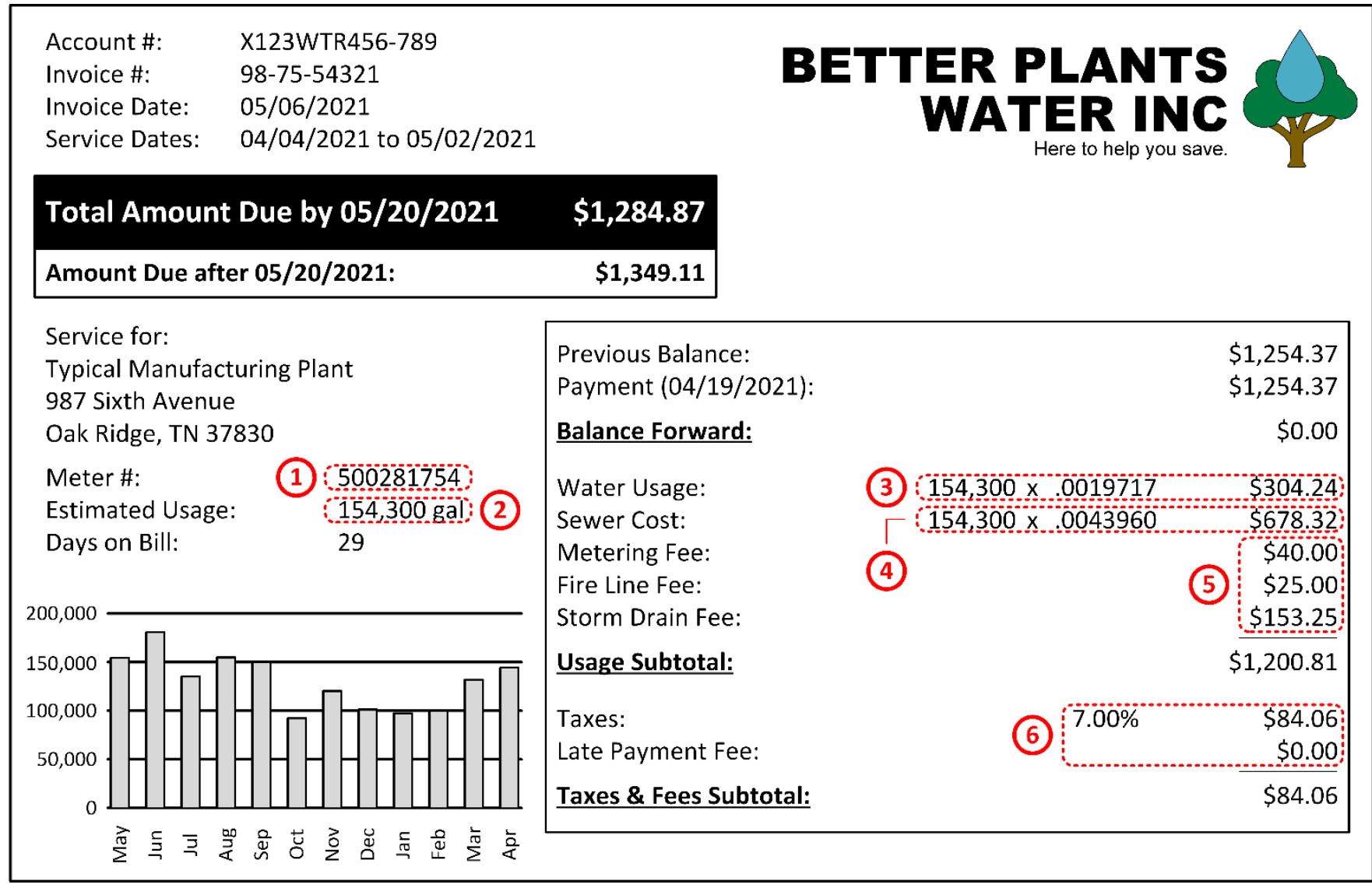

Figure 5: Example utility bill with key information highlighted: (1) Meter number, (2) Meter reading, (3) Usage charge, (4) Sewer Charge, (5) Miscellaneous Fees, (6) Taxes and Late Fee. 


\subsection{Consumption Charges}

Water consumption charges, or usage charges, are a variable charge based on the volume of incoming water. Consumption is measured by a meter at the water system inlet to the facility. Water meters can be labeled with valuable information such as the diameter of the incoming pipe or, most importantly, the units that the meter is reading. The majority of meters in the US read either gallons or cubic feet. Similar to electric meters, water meters can come in a few different varieties, but are usually digital, analog, or dial. Digital meters are the simplest to read, with an LCD display and a solar cell for power. Analog meters can be a little trickier. Analog meters are read by reading the rolling tick dial which records to the tens place. The analog meter in Figure 6 shows that the last whole number is stationary at zero, the value in the red box will not change. Instead, the last whole digit is read by reading the sweeping hand and rounding down to the nearest labeled number. Finally, a dial meter has an individual dial for each tens place, where the ones place is typically used as a low-flow indicator. For example, the meters in Figure 6 all read 316,426 gallons. Analog meters also commonly include a triangle or star-shaped rotating low-flow indicator. Low-flow indicators are used to visually confirm that flow is feeding into the facility and can be used as a signal of a water leak. Digital meters can have a similar feature with a dedicated low-flow indicator.

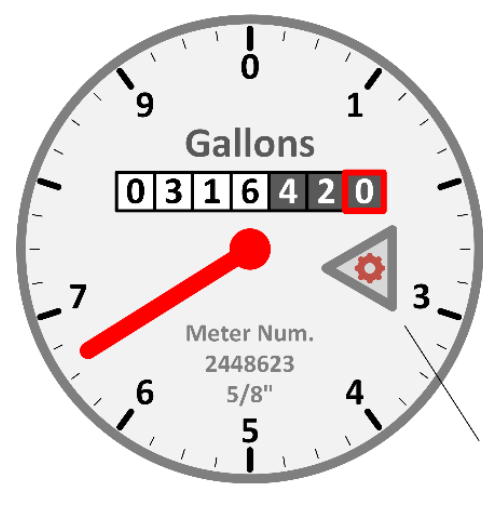

(a) Analog

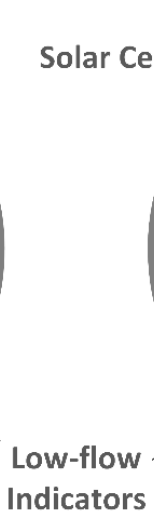

Indicators

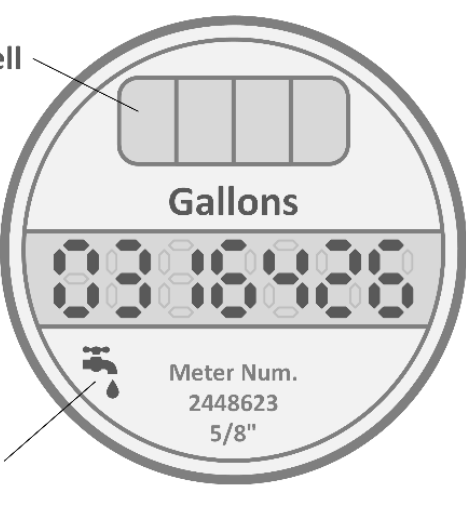

(b) Digital

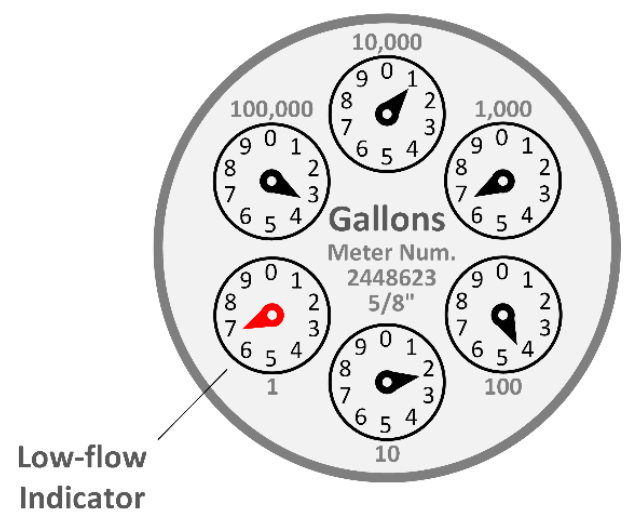

(c) Dial

Figure 6: Common Types of Water Meters. ${ }^{7}$

Incoming water can be provided from different sources. Depending on the source and quality of the water required, consumption charges can vary. Water is most commonly provided through the municipal water system and is treated to the municipal standard. However, some facilities are able to use an industrial water source that may not be as rigorously treated but has a lower cost. For rural or temporary operations, other sources of water can also include water trucks that transport water from other locations.

\subsection{Sewer Treatment Charges}

Sewer charges are calculated based on the volume of outgoing or discharged water from your facility. This water is considered dirty or used water. Water that is charged for sewer treatment is sent to a wastewater treatment facility to be sanitized and treated for pathogens and impurities. Sewer charges go toward funding these wastewater treatment plants as well as general maintenance and sewer system upkeep.

Sewer charges are billed similarly to consumption charges in that they are a variable charge based on a meter reading. If your facility does not have a sewer meter, water tariffs will generally assume that the volume of effluent water (water exiting the facility) is equal to the influent water volume (water entering the facility); more simply,

${ }^{7}$ Adapted from Smart Home Water Guide, "How to Read your Water Meter," https://www.smarthomewaterguide.org/how-to-read-yourwater-meter. 
water in equals water out. Having a single meter for consumption is common for smaller facilities or for facilities whose processes do not consume a large percentage of the water.

Some facilities may have a dedicated sewer water meter to measure their effluent water volume. This is common for industries such as food and beverage, chemical process, and textiles manufacturing that consume large amounts of water in their processes. Examples of water not returned to the sewer include water that is evaporated in cooling towers, or the water that is used to dilute chemical products. Metering incoming and exiting water allows these facilities to avoid paying sewer costs for water that does not use the sewer system. Alternatively, if you can pinpoint a process that evaporates a large portion of your water, you may also apply for an evaporation credit. If you can quantify the volume of water being evaporated (and not going to the sewer), most utilities will offer a credit to subsidize the sewer cost. Evaporation credits are discussed in more detail in Section 5.2 of this document.

Industrial facilities may have additional steps for their sewer water disposal. Some industries must discharge wastewater that requires additional treatment. To subsidize the additional treatment cost, wastewater facilities will charge a sewer treatment surcharge based on the concentration of a specific contaminant. The containments and concentrations are predetermined, and customers will be given a permit to discharge the water to the sewer. Every treatment facility is different and will only accept specific amounts and types of containments. Common items subject to surcharge include excessive suspended solids, nitrogen, fats, oils, grease, phosphorous, and others depending on your service provider.

Although some facilities will choose to treat this water themselves, others have the option to send it to a specialized industrial wastewater treatment center or will use a third-party disposal company. Facilities with industrial sewer charges typically also have separate municipal sewer lines. One sewer line leads to the municipal treatment center, while the other leads to the industrial treatment center. To offset the cost of additional treatment, industrial sewer charges are more expensive than the standard municipal sewer charge. Managing water streams in these cases is important to avoid unnecessary industrial sewer charges for water that can be sent to the cheaper municipal treatment plant.

\subsection{Additional Fees and Charges}

Your bills may also show multiple charges that are not based on your metered water volume. These charges are typically riders or taxes that are associated with the maintenance of the infrastructure in the water system or environmental regulatory costs. This section details the most common additional fees seen on industrial water bills.

\section{Meter and Customer Fees}

A customer fee is a fixed charge assessed each month for providing water service to your facility. This charge covers utility operating costs related to overhead and customer service. Metering fees are a flat fee used to offset the costs of measuring your usage. These fees cover technicians physically reading your meters and providing basic maintenance on the meter. Meter fees vary based on the size of the meter, with larger pipes requiring larger meters and, therefore, higher metering fees. Standard sizing for residential use ranges from $5 / 8$ to 1 inch while industrials meters can be well over 6 inches. If your facility has multiple water meters, you can expect multiple meter fees on your bills. Some utilities combine customer fees and metering fees into a single charge.

\section{Taxes}

Like standard sales taxes, water usage taxes are a percentage of the billed cost. Depending on the region, taxes can be collected by the state, county, or city. Most facilities can expect to see their standard state sales tax assessed on their bills. Some manufacturing facilities may be able to claim an exemption from state sales tax. Sales tax exemptions are typically associated with the fabrication process, meaning that if a facility can prove a certain 
portion of the water is for manufacturing purposes, the tax charge can be lowered or removed. Consult with your local utility provider to see if a manufacturing tax exemption is available for your facility.

\section{Storm Drain Fees}

As structures are built, rainwater is unable to be absorbed by the newly covered ground. However, this water still needs to go somewhere. The goal of a storm drain is to reroute uncaptured water from rain, snow melt, or excess landscaping through a system of pipes and drains. This water system is usually separate from the sewer system and is routed to local reservoirs, rivers, or treatment facilities. Water in the storm drain system is not potable due to debris and sludge that is washed off roads by rainwater. This water eventually rejoins the urban water cycle and is treated for consumption. To offset the cost of developing and maintaining this infrastructure, some customers are charged a storm drain fee. Fees can be either a standard fixed monthly cost or based on the area of impervious ground surface such as buildings and parking lots. Example 1 depicts a case in which the storm drain charge is based on the impervious ground surface area.

\section{Example 1: Storm Drain Charges}

A manufacturing plant's utility bill has a storm drain charge of $\$ 2.35$ per $1,000 \mathrm{ft}^{2}$ of nonporous area per month. The plant wants to build a new warehouse that is $23,000 \mathrm{ft}^{2}$. Calculate the annual storm drain charge the facility will have to pay for the new warehouse.

Known: Square footage of the new warehouse and the monthly storm drain rate

Calculate: Annual cost for the storm drain fee for the new warehouse, $\left(C_{\mathrm{SD}}\right)$

$$
\begin{aligned}
C_{S D} & =\text { Monthly Storm Rate } \times \text { Square Footage of New Warehouse } \times 12 \text { months } / y r \\
& =\frac{\$ 2.35}{1,000 f t^{2} / \text { month }} \times 23,300 f t^{2} \times 12^{\text {months }} / y r=\$ 648.60 / y r
\end{aligned}
$$

\section{Fire Line Fees}

Fire line fees, or hydrant fees, are used for customers with private fire protection lines. This water line is used solely in case of a fire and is charged based on the line type or size. Utilities set this fee based on how the water is delivered (e.g., sprinkler systems, hydrants, pumps) as well as the diameter of the line that is being supplied. Fire line fees are usually a monthly flat fee to ensure that water can be provided at a moment's notice. The only time a fire line should be charged for consumption would be in the case of a leak or if it was used in an emergency.

\section{Standby Fees}

A standby fee has two meanings, depending on your location. First, a standby fee can refer to a fee that is imposed on undeveloped property in anticipation that the parcel will require potable water, sewer, or drainage services in the future. This fee is typically collected simultaneously with property taxes and is not on your water bills.

Second, standby fees are similar to electrical demand response programs. You may see standby fees in droughtprone areas or in rural areas where the majority of local water is consumed by industry. In times when water demand is higher than the supply, the utility company can call an "event," where industrial consumers are instructed to reduce or stop their water consumption for a period of time during which water will be routed to residential areas, hospitals, or emergency services. If you do not respond to a standby event, an associated penalty will be on your bill. To avoid this penalty, customers must react when called to respond to a standby event. 


\subsection{True Cost of Water}

When analyzing water bills or considering implementation of a project that will affect the water consumption, you should consider your true cost of water. Utility bills only reflect the direct unit cost for incoming water and sewer usage, but there are more costs associated with water commonly overlooked. This section has only focused on items that are explicitly listed on your bills, but there are other costs you should consider while finding your true cost of water.

Once water enters a facility, energy is used to move it, process it, and heat or cool it (Figure 7). These costs are considered indirect costs associated with the water. In many cases, facilities will find that their true cost of water is much higher than their billed unit cost. For example, in the beverage industry, it is common to have a true cost of that is 2-4 times higher than the direct unit cost from their water bills. In many cases, the true cost of water can be double or even triple the direct unit cost of water from your bills ${ }^{8}$. By using the true cost of water, a macro perspective can be used during project evaluations. To assist partners with calculating their true cost of water, the Better Plants program has developed the Plant Water Profiler Tool ${ }^{9}$ (PWPEx). The PWPEx Tool is available online at the Better Plants Program website. The tool is discussed in more detail in Section 5.6 of this document.

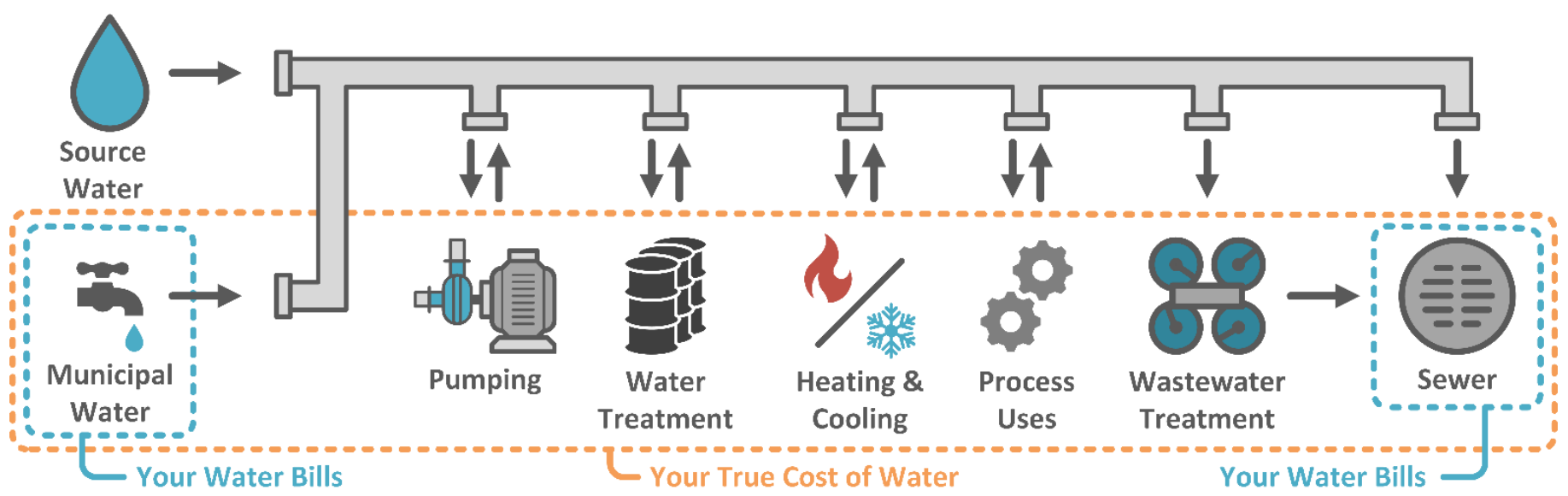

Figure 7: The True Cost of Water.

8 Prigge J., "Ideas for using the true cost of water in sustainability strategy" March 22, 2019, https://www.greenbiz.com/article/ideas-usingtrue-cost-water-sustainability-strategy.

9 US Department of Energy, Office of Energy Efficiency \& Renewable Energy, "Plant Water Profiler Tool-Excel, Version 1.0 (PWPEx v1.0)," https://www.energy.gov/eere/amo/plant-water-profiler-tool-excel-version-10-pwpex-v10. 


\subsection{Calendarization}

As you examine each month's water bills, take note of how many days are on each invoice. It may become frustratingly apparent that the number of days on each bill can be quite different. Depending on when your meters are read, some billing periods can have fewer than 25 days, while others can be close to 35 days. When comparing between years, months, or with other utilities like natural gas and electricity, having consistent billing periods is essential. This variation can lead to skewed bill analysis if the monthly bills are not normalized. This can also be an important step if the water and sewer bills are from different entities. Your sewer bill may be billed on different dates than water, in which case adjusting the billing data is highly recommended.

The process of adjusting utility data to normalize for billing periods is known as calendarization. Although beyond the scope of this document, standard practice is to divide consumption by the number of billing days and allocate to each month an appropriate number of days from each bill. More information on calendarization can be found in the Better Plants Energy Intensity Baselining and Tracking Guidance $2020^{10}$, which can be found on the Better Plants Solution Center website. The baselining document was primarily developed for energy tracking, but the same principles apply to water and sewer tracking.

10 Price, C., Nimbalkar, S., and Wenning, T., Energy Intensity Baselining and Tracking Guidance (United States: Oak Ridge National Laboratory, Oak Ridge, TN, August 22, 2020), https://www.osti.gov/biblio/1649123. 


\section{Common Water Rate Structures}

Every water company or municipality will dictate water rates in their water tariff. Rate structures for different regions can vary vastly based on supply and demand as well as environmental constraints. Understanding what rate is used can assist in baselining your facility's water consumption and help with cost-saving projects in the future. These rates are per unit rates, meaning that they are applied to the volume readings found on a facility's meter. This charge is used to fund the chemical treatment process for the water before delivery as well as infrastructure support and maintenance. The five most common rate structure that are found with utility companies are uniform rates, decreasing block rates, increasing block rates, drought rates, and seasonal rates. The following graphs give a visual representation of the rate structure and an explanation of why these structures may be used ${ }^{11}$.

\subsection{Uniform Rates}

The simplest rate structure is the uniform rate, which is also known as a constant/fixed rate or constant block rate. This rate structure is most common on utility bills for residential and small manufacturing customers. Regardless of the customer's water consumption, the unit price will stay the same. Uniform rates encourage water conservation by providing a clear cost benefit for reducing usage.

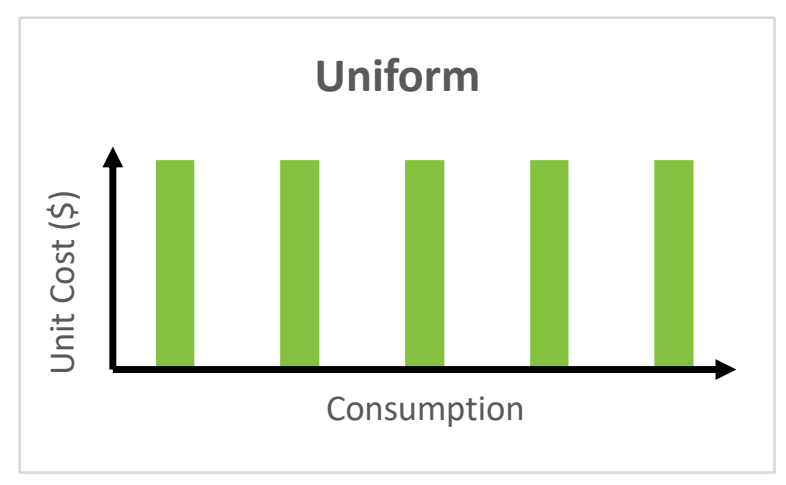

\subsection{Block Rates}

Block rates are a common variable rate structure often used with water utilities. With block rates, your unit cost for water will be divided into distinct tiers based on your usage. The two block rates often used on water bills are increasing and decreasing block rates. With decreasing block rates, the unit cost of water decreases as more water is used. After a consumption tier is full, usage moves to the next block at the cheaper rate. This rate is most often found in rural areas for agricultural use and heavy industry in regions where water is plentiful.

With increasing block rates, the unit cost of water increases as more water is used. Similar to decreasing rates, after a consumption tier is full, usage moves to the next block, which now has a more expensive rate. This rate system encourages conservation by increasing costs as more water is consumed. Increasing block rates are commonly found in more urban areas where the supply of water is not plentiful or where water usage is more restricted.
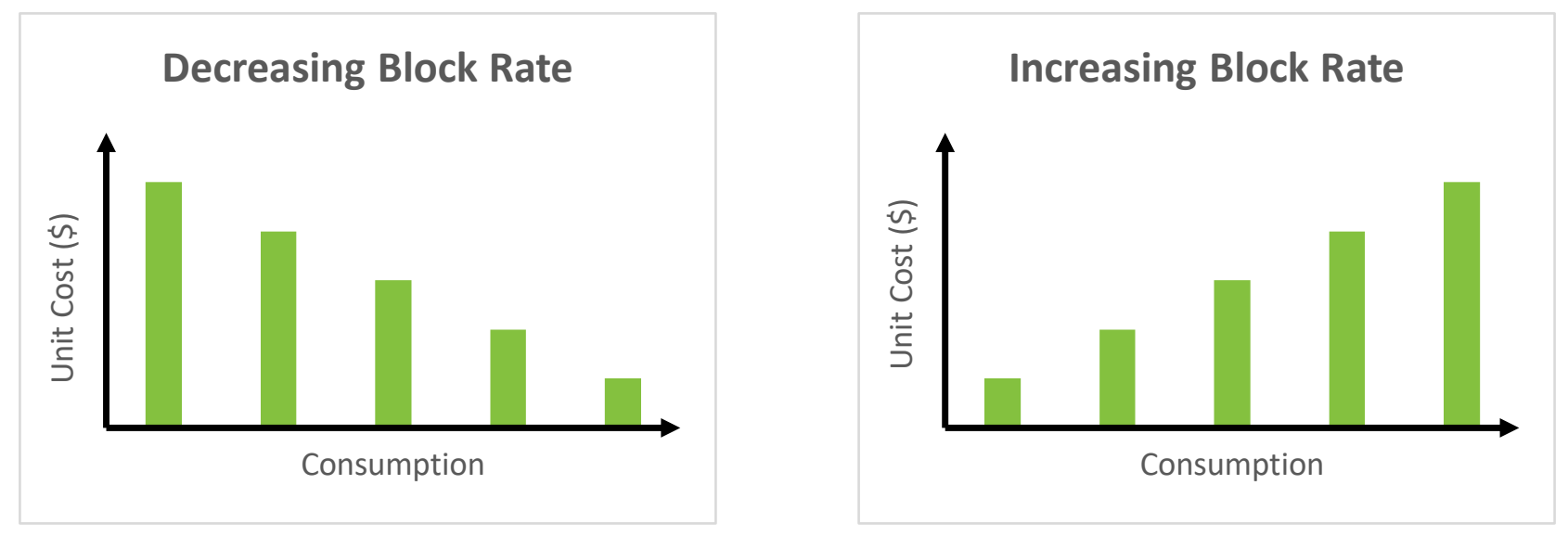

11 Graphs adapted from: US Environmental Protection Agency. "Understanding Your Water Bill," https://www.epa.gov/watersense/understanding-your-water-bill. 


\subsection{Time-of-Use Rates}

Water rates can also take the form of time-of-use rates, which are based on the supply and demand of water. When supply is high, the unit cost decreases, but when the supply is low, the unit cost increases. The two most common time-of-use rates are drought rates and seasonal rates. A drought rate is found in regions where droughts are experienced intermittently. When rainfall is limited, the water in the cycle is lessened, requiring those regions to conserve water. During drought seasons, rates are adjusted upward to discourage usage. Higher levels of drought lead to higher unit costs of water. This structure encourages water conservation during specific conditions.

Seasonal rates are similar to drought rates in that water costs more in particular seasons. Rates usually increase in the summer when less precipitation occurs and decrease in off-seasons that have more/regular precipitation. This rate is typically either on or off-season and does not change with precipitation rates or drought levels.
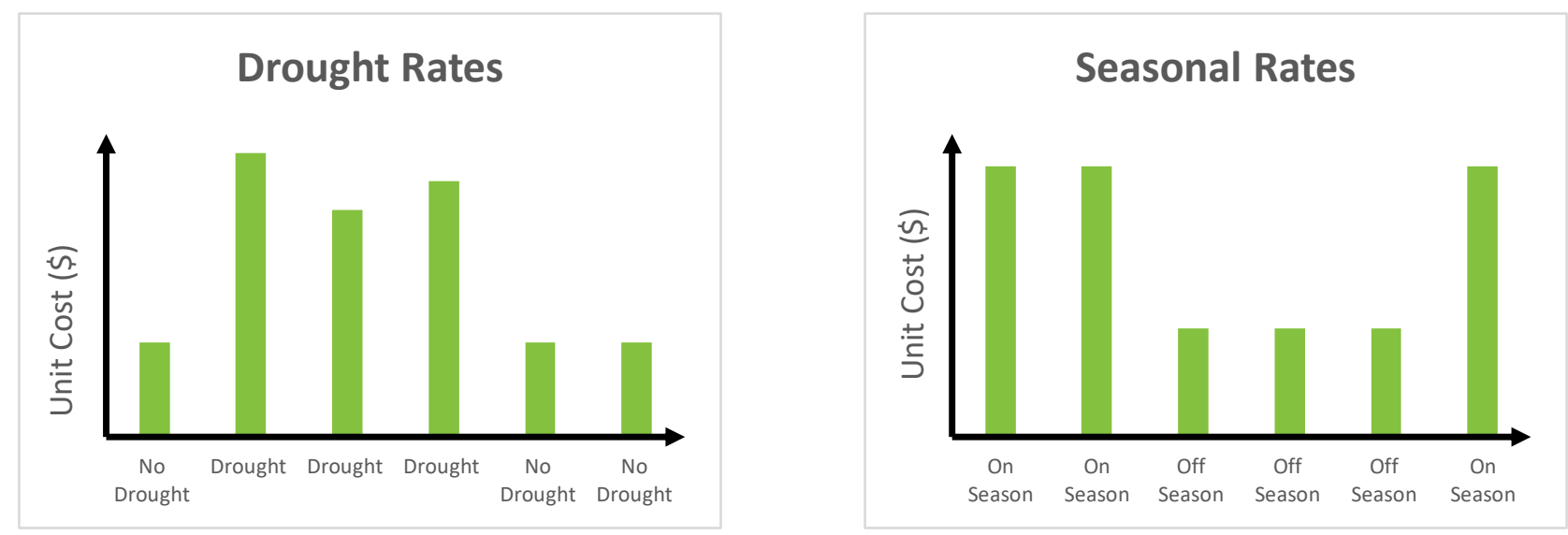


\section{$5 \quad$ Saving Opportunities from Water Bill Analysis}

The previous sections have discussed the items that are commonly seen on a water utility bill and why those charges are used. The following sections discuss ways to save costs on your water bills without necessarily conserving water. With a thorough analysis of the bills, your facility can save money by making a few adjustments to the rate tariffs or by making minor changes to how the water is measured.

\subsection{Sewer Water Metering}

As stated in Section 3, all facilities have a meter on incoming water. However, not all facilities have a separate sewer meter to measure outgoing water. When a facility does not have a sewer meter, the utility will assume that the incoming water volume is equal to the outgoing water volume. Although this is a fair assumption for many facilities, for others the difference between incoming and outgoing water volumes can be substantial. This difference can particularly be seen with facilities that have water-intensive processes or that make products that contain water such as the food and beverage, chemical processing, and textile industries. Installing a sewer meter reduces the volume of sewer usage shown on invoices and avoids unnecessary sewer expenses. Example 2 depicts a case in which installing a sewer water meter can lead to substantial sewer bill savings.

\section{Example 2: Installing a Sewer Water Meter}

A food manufacturing plant produces baked goods and bread. The facility uses roughly 300,000 gallons of water per month. Currently, the facility has no sewer meter, and their utility bill assumes that the sewer volume is equal to their incoming volume. The plant knows that $60 \%$ of their water usage is evaporated out of the dough during the baking process and does not return to the sewer. If the current sewer rate is $\$ 0.006 /$ gal, calculate how much the plant will save by installing a sewer meter.

Known: Total incoming water per month, percentage of water that is consumed by the product, and the current sewer rate

Calculate: Annual savings if a sewer meter were installed

Cost Savings $=$ Incoming Water Volume $\times$ Percent of Water Used in Product $\times$ Sewer Rate

$$
=300,000 \frac{\text { gal }}{\text { month }} \times 60 \% \times \frac{\$ 0.006}{\text { gal }}=\frac{\$ 1,080}{\text { month }} \text { or } \frac{\$ 12,960}{\text { year }}
$$

\subsection{Evaporation Credits}

Evaporation credits, also known as sewer credits, can help reduce your water bill. These credits are used in facilities that have a large amount of water not discharged into the sewer and who don't have a dedicated sewer meter. Evaporation credits were designed to alleviate the sewer cost when the used water is being evaporated or consumed rather than discharged into the sewer. Evaporation from cooling water towers is a common industrial process that is often granted evaporation credits. Other industries that could benefit from evaporation credits for water embedded into the product include industrial laundries, textiles, food and beverage, and chemicals. Utilities that offer an evaporation credit program must be able to quantify the amount of water that is being evaporated. For some utilities, a calculation showing the evaporated quantity will suffice, while others will require a meter on makeup water or somewhere within the evaporative or consumption process. Example 3 shows a case where an evaporation credit can be applied to the use of a cooling tower. 


\section{Example 3: Evaporation Credit}

A manufacturing plant uses chilled water for both process and comfort cooling. The chiller is water-cooled and utilizes a cooling tower for heat removal. The plant adds make-up water to replace evaporated water from the tower, and simultaneously discharges bleed-off water to the sewer to maintain the appropriate concentration of dissolved solids. The plant monitors both the make-up water rate (12,000 gal/day) and the bleed-off rate (4,500 gal/day). The difference between these two values is the estimated evaporation volume. If the current sewer rate is $\$ 0.003 /$ gal and the drift rate is negligible, calculate how much of an evaporation credit the plant could receive.

Known: Make-up water rate, bleed-off rate, and the current sewer rate.

Calculate: Annual savings if an evaporation credit is applied

$$
\begin{gathered}
\text { Evaporated Water Volume }=\text { Make-up Water }- \text { Bleed-off Water } \\
=12,000 \frac{\text { gal }}{\text { day }}-4,500 \frac{\text { gal }}{\text { day }}=7,500 \frac{\text { gal }}{\text { day }}
\end{gathered}
$$

Evaporation Credit Savings = Evaporation Rate $\times$ Sewer Rate

$$
=7,500 \frac{\text { gal }}{\text { day }} \times 30 \frac{\text { days }}{\text { month }} \times \frac{\$ 0.003}{\text { gal }}=\frac{\$ 675}{\text { month }} \text { or } \frac{\$ 8,100}{\text { year }}
$$

\subsection{Discharge Water to Appropriate Places}

Some industries are required to discharge their industrial water to an industrial sewer treatment center. These special treatment centers are designed to process water through a more rigorous treatment process than the standard municipal water system; thus, industrial sewer charges are much higher than standard sewer charges. Facilities that are required to separate their process and comfort water should ensure that only contaminated process water is discharged to the industrial treatment sewers. If a separate sewer line for comfort water or noncontaminated water exists, then the comfort water should be discharged to the standard municipal treatment center. This change will lead to direct sewer cost savings while not affecting the current volume of water being used at the facility.

\subsection{Using Suitable Sources of Water}

Similar to having dedicated sewers for industrial discharge, there are also sources of water available through local municipalities specifically for industrial use. Depending on the manufacturing sector, industrial water sources are appropriate for some facilities. Industrial water is usually treated to a lower level than the typical municipal water supply and is much cheaper. Because of less rigorous treatment, this water is less clean and contains more impurities. Additionally, a source of water for industrial use that should be considered is recycled or non-potable water. If the facility has access to and can use industrial or recycled water, cost savings can be substantial. These water sources are not appropriate for all industries due to quality and safety concerns, but where possible, its use can save costs while maintaining the same volume of water. 


\subsection{Analyzing Your Water Usage}

Water-consuming systems in industrial manufacturing plants include processes, cooling and condensing systems, power generation, air conditioning, steam boilers, kitchen and restrooms, landscaping and irrigation, and fire sprinkler systems.

DOE's PWPEX Tool helps break down the total plant water intake, wastewater disposal, and the true cost of water by individual systems in a manufacturing plant. This helps management identify the systems that contribute the most toward water resource usage versus the true cost and enables efforts to prioritize water efficiency measures. Figure 8 shows examples of the systems that contribute toward the true cost of water. Results can also be used to establish a baseline and track water use during subsequent years.

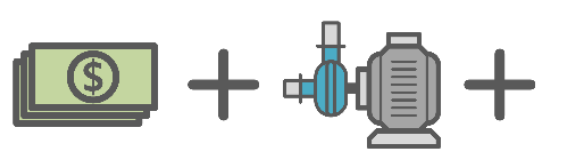

Purchasing

$$
\text { Pumping }
$$

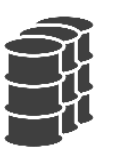

Water Treatment

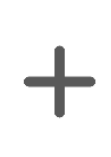

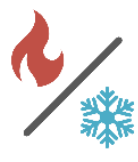

Heating \&

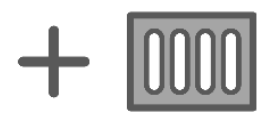

Sewer

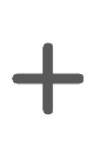

Wastewater
Treatment

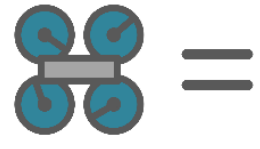

True Cost of Water

Figure 8: Components of the True Cost of Water.

The PWPEx Tool evaluates water balance by individual systems, accounting for the source water intake, recirculated water, consumptive water use, and wastewater disposal. This helps management estimate water losses as well as potential water and true cost savings that can be achieved from increasing water recirculation and eliminating water losses. Figure 9 is a detailed concept map of the PWPEx Tool that shows the considerations needed for a proper facility water balance. The PWPEx Tool assesses the water efficiency status of a plant and its individual systems and provides a tailored list of water efficiency measures and opportunities specific to the plant. Thus, the PWP Tool is a "first step" that industrial manufacturing plants can follow to minimize their water use and achieve cost savings. The $\underline{\text { PEPEX Tool }}{ }^{9}$ can be found for download online at the Better Plants website.

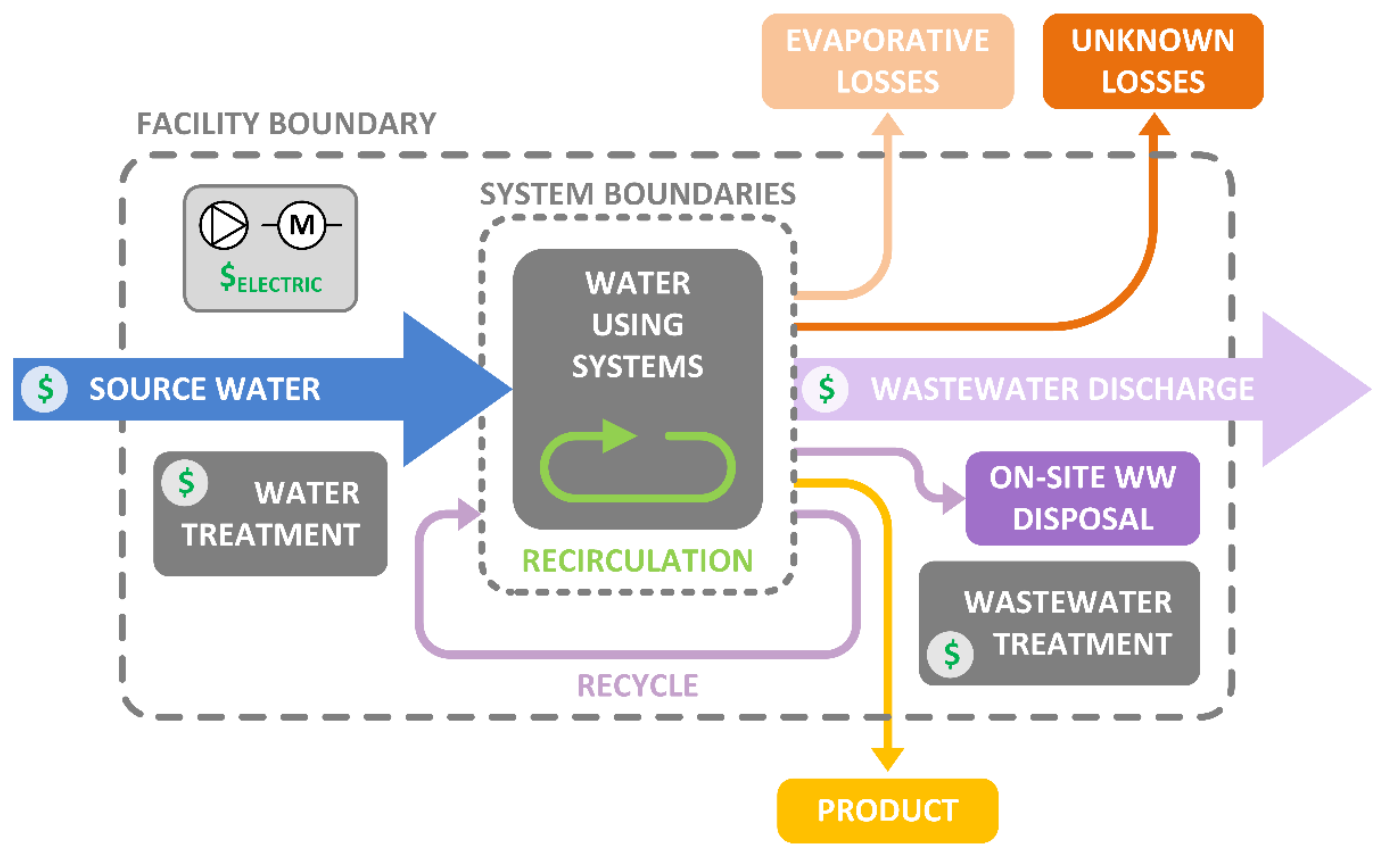

Figure 9: Plant Water Profiler Concept Map. 


\subsection{Tax Exemptions}

When reviewing your utility bills, pay attention to any listed taxes. Many states allow manufacturing facilities to claim a state sales tax exemption on their utility bills if a certain percentage of incoming water to their facility is used for production purposes ${ }^{12}$. Activities such as purchasing, maintenance, testing, storage, and so on are not usually eligible toward tax exemption. A predominant use study from an independent third party is typically required to claim the exemption. Some states will even refund up to 24 months of back taxes after claiming the exemption. Consult with your local utility to see if your state offers any tax exemptions for manufacturers.

\subsection{Avoiding Late Fees}

Almost every company (including utilities) charges a late fee when a payment is overdue. The exact size of the fee varies, but some utilities can charge as much as $10 \%$ of the outstanding balance. When bills are not paid, your facility is effectively borrowing money at an extremely high annual percentage rate. For example, a late fee of just $5 \%$ has an effective annual percentage rate of $80 \%$. Working with your billing department and your utility can help you avoid these fees. Simple things such as understanding if a payment must be postmarked or received by the due date can save a lot of money over time.

\subsection{Recreate Your Bills}

Once you know your rate structure, you now can double-check the charges on your bills. Every consumption and sewer charge can be verified by using the line items in your rate structure and the meter readings from the bill. The goal is to balance the charges on the bills with your understanding of your rate structure. Generally, three possible outcomes can happen.

1. Your Calculation Matches the Bills: This is the ideal case; you have identified the correct rate structure and no calculation errors occurred on your bills.

2. Incorrect Rate Structure: Your estimated bill does not match your actual bill because you are using the wrong rate structure. Understanding which rate structure you are under is key to avoiding unnecessary water expenses.

3. Calculation Error: Your estimated bill does not match your actual bill because of an error on your bill. Failed meters, data entry issues, and clerical errors are a few issues that can occur. Catching these mistakes early can save time and money down the road.

12 SM Engineering Co., "State Sales Tax Exemptions for Manufacturers," June 20, 2014, https://www.smeng.com/manufacturing-sales-taxexemptions/. 


\section{$6 \quad$ Performing a Utility Bill Analysis: An Example}

This section provides a detailed analysis of 12 months of sample water and sewer bill data. The example highlights several key concepts discussed in this document. The numbers presented, although based on actual bills, have been randomized. The appearance of specific water suppliers is not an endorsement but is used to discuss actual rate structures for water and sewer. Your Better Plants TAM is available for any assistance you may need to understand the analysis and can help you perform a similar analysis on your own bills.

\subsection{Rate Structure}

Fine Factories Incorporated (FFI) has a manufacturing facility located outside of Huntington, West Virginia. The facility requires a 4 -inch service pipe and has an average monthly water consumption of 408,724 gal. Because of their high water usage, FFI falls under West Virginia-American Water Company's industrial block tariff. FFI also pays the Huntington Sanitary Board for sewage disposal. Table 1 shows the block rate structure for the FFI's water consumption, and

Table 2 shows the block rate structure for their sewer charge. Table 3 reflects other related charges and fees. Full local rate structures can be found online.

Table 1: FFI Industrial Water Block Tariff.

\begin{tabular}{|lrl|}
\hline & Block Tier & Rate \\
\hline First & 1,500 & gallons used per month at the minimum charge \\
\hline Next & 28,500 & gallons used per month $\$ 13.9450$ per 1,000 gallons \\
\hline Next & 870,000 & gallons used per month $\$ 9.16800$ per 1,000 gallons \\
\hline Next & $8,100,000$ & gallons used per month $\$ 6.67700$ per 1,000 gallons \\
\hline All Over & $9,000,000$ & gallons used per month $\$ 4.34300$ per 1,000 gallons \\
\hline
\end{tabular}

Table 2: FFI Industrial Sewer Block Tariff.

\begin{tabular}{|lrl|}
\hline & \multicolumn{1}{|c|}{ Block Tier } & Rate \\
\hline First & 2,000 & gallons used per month $\$ 10.40$ per 1,000 gallons \\
\hline All Over & 2,000 & gallons used per month $\$ 5.35$ per 1,000 gallons \\
\hline
\end{tabular}

Table 3: Charges and Fees for FFI Water Service.

\begin{tabular}{|lccc|}
\hline Charge & Rate & Unit & Charge Type \\
\hline Meter Fee for 4-inch meter: & $\$ 760.76$ & Per month & Fixed \\
\hline Fire line Fee: & $\$ 37.25$ & Per month & Fixed \\
\hline Storm Drain Fee: & $\$ 57.32$ & Per month & Fixed \\
\hline
\end{tabular}




\subsection{Water Bill}

FFI's water supplier bundles their water and sewer service into a single bill (Figure 10). The bill lists the current and previous meter readings, the current month's consumption and sewer usage, the account balance, and a list of current charges. To understand this bill, the rate schedule and some independent calculations are required.

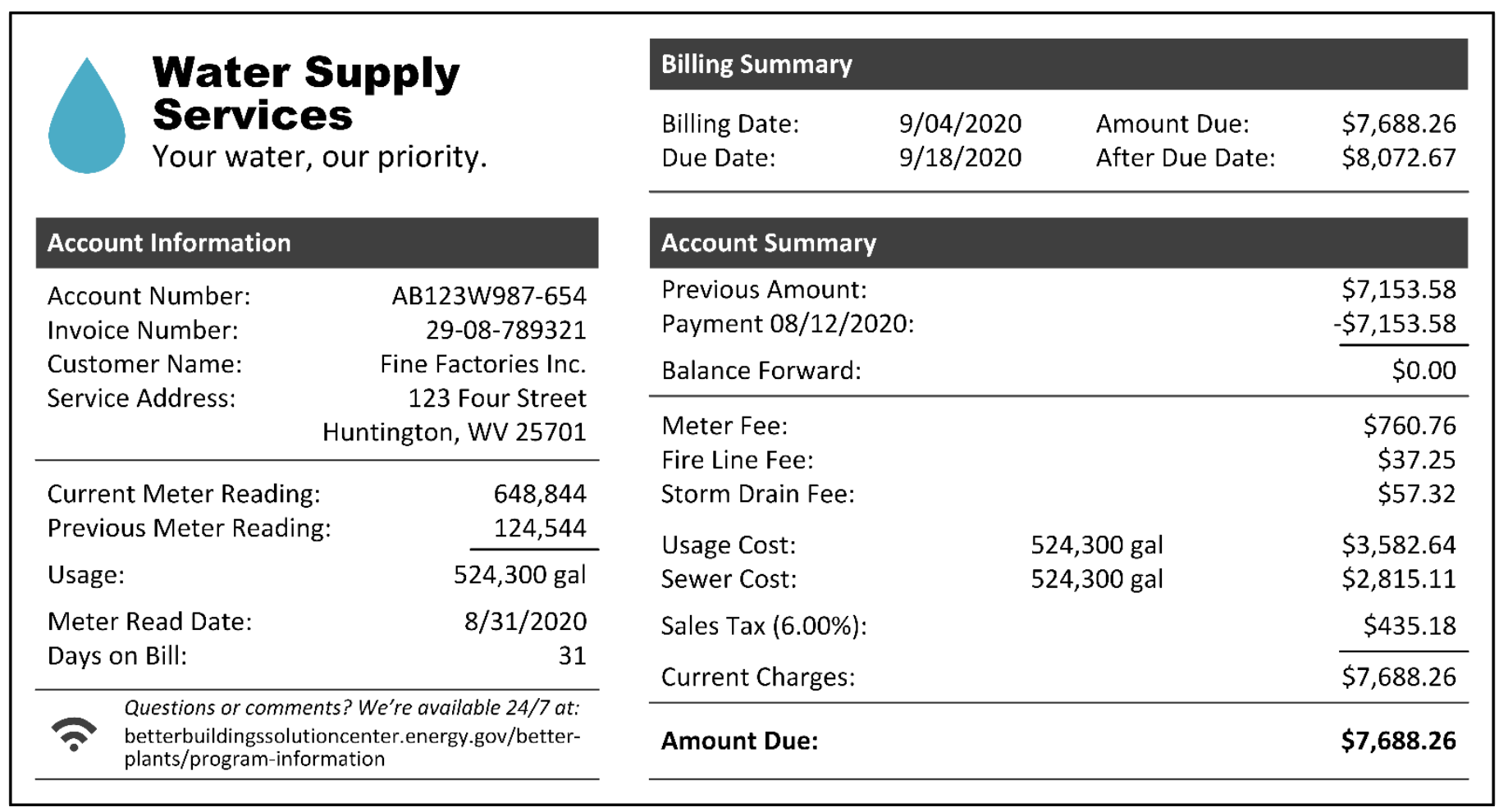

Figure 10: Example Water Bill for FFI.

Using historical utility bill data and the meter readings on the bill in Figure 10, the following analysis recreates each listed charge.

\section{Water and Sewer Readings}

FFI does not have a separate sewer meter, so the sewer and water volume are assumed to be equal. The current month's water and sewer readings are calculated by taking the difference between the current and previous meter readings:

$$
\begin{gathered}
\text { Total Volume }=(\text { Current Reading }- \text { Previous Reading }) \\
=(648,844-124,544)=524,300 \mathrm{gal}
\end{gathered}
$$

\section{Water Usage Charge}

FFI is currently on a tariff with a decreasing block rate meaning that the unit water cost becomes cheaper with more usage. To calculate the water consumption cost, the water usage must be separated into its respective blocks.

Equation 1 gives the formula for determining the volume of water in each block. Starting with the usage listed on the bill, the first block cap is 1,500 gallons, which is less than the total volume. Block 1 consumption is therefore 1,500 gallons. The second block cap is 28,500 gallons, which is less than the remaining consumption of $524,300-$ $1,500=522,800$ gallons. Block 2 consumption is therefore 28,500 gallons. This process continues until all usage is assigned to a block. The following equations and Table 4 summarize this process. 


$$
\text { Block Volume }=\min [(\text { Remaining }- \text { Previous Block Limit }) \text { or Current Block Limit }]
$$

Table 4: Volume of Water in Each Block for FFI Water Service.

\begin{tabular}{|c|c|c|c|c|}
\hline Block Tier & Unit Cost & Block Limit & Customer Volume in Block & Remaining Total \\
\hline Block 1 & $\$ 0.013940$ & 1,500 & 1,500 & 522,800 \\
\hline Block 2 & $\$ 0.009168$ & 28,500 & 28,500 & 494,300 \\
\hline Block 3 & $\$ 0.006677$ & 870,000 & 494,300 & 0 \\
\hline \multicolumn{5}{|c|}{$\begin{aligned} \text { Block } 1 \text { Volume } & =\min [(524,300-0) \text { or Block } 1 \text { Limit }] \\
& =\min [524,300 \text { or } 1,500]=1,500 \text { gal }\end{aligned}$} \\
\hline \multicolumn{5}{|c|}{$\begin{aligned} \text { Block } 2 \text { Volume } & =\min [(524,300-1,500) \text { or Block } 2 \text { Limit }] \\
& =\min [522,800 \text { or } 28,500]=28,500 \mathrm{gal}\end{aligned}$} \\
\hline \multicolumn{5}{|c|}{$\begin{aligned} \text { Block } 3 \text { Volume } & =\min [(522,800-28,500) \text { or Block } 3 \text { Limit }] \\
& =\min [494,300 \text { or } 870,000]=494,300 \mathrm{gal}\end{aligned}$} \\
\hline
\end{tabular}

The current month's consumption cost is then calculated by multiplying the volume in each block by the respective block rate. The summation of the block charges gives the total consumption charge for the month:

$$
\begin{aligned}
\text { Block Charge } & =\text { Volume in Block } \times \text { Block Unit Charge } \\
\text { Block } 1 \text { Charge } & =1,500 \mathrm{gal} \times \$ 0.013940 / \text { gal }=\$ 20.91 \\
\text { Block } 2 \text { Charge } & =28,500 \mathrm{gal} \times \$ 0.009168 / \text { gal }=\$ 261.29 \\
\text { Block } 3 \text { Charge } & =494,300 \text { gal } \times \$ 0.006677 / \text { gal }=\$ 3,300.44 \\
\text { Total Water Usage Charge } & =\text { Block } 1 \text { Charge }+ \text { Block } 2 \text { Charge }+ \text { Block } 3 \text { Charge } \\
& =\$ 20.91+\$ 261.29+\$ 3,300.44=\$ 3,582.64
\end{aligned}
$$

\section{Sewer Disposal Charge}

FFI does not have sewer meter; thus, the total sewer volume is assumed to be equal to the total usage volume. To calculate the sewer disposal cost, the sewer volume must be separated into its respective blocks. Similar to the water bill, the sewer charge is in an increasing two-block tariff. Using equation 1 , the block 1 volume is found to be 2,000-gal, and the block 2 volume is 524,300 -2,000 =522,300 gal. Because block-2 has no limit, the remaining volume will be in block 2 . The following equations and Table 5 summarize this process.

Table 5: Volume of Sewer Disposal in Each Block for FFI Sewer Service.

\begin{tabular}{|ccccc|}
\hline Block Tier & Unit Cost & Block Limit & Customer Volume in Block & Remaining Total \\
\hline Block 1 & $\$ 0.01040$ & 2,000 & 2,000 & 522,300 \\
\hline Block 2 & $\$ 0.00535$ & No Limit & 522,300 & 0 \\
\hline
\end{tabular}

$$
\begin{aligned}
& \text { Block } 1 \text { Volume }=\min [(524,300-0) \text { or Block } 1 \text { Limit }] \\
& =\min [524,300 \text { or } 2,000]=2,000 \mathrm{gal} \\
& \text { Block } 2 \text { Volume }=524,300-2,000=522,300 \mathrm{gal}
\end{aligned}
$$


The current month's sewer disposal cost is then calculated by multiplying the volume in each block by the respective block rate. The summation of the block charges gives the total sewer charge for the month:

$$
\begin{aligned}
& \text { Block Charge }=\text { Volume in Block } \times \text { Block Unit Charge } \\
& \text { Block } 1 \text { Charge }=2,000 \mathrm{gal} \times \$ 0.01040 / \mathrm{gal}=\$ 20.80 \\
& \text { Block } 2 \text { Charge }=522,300 \mathrm{gal} \times \$ 0.00535 / \mathrm{gal}=\$ 2,794.31 \\
& \text { Total Water Usage Charge }=\text { Block } 1 \text { Charge }+ \text { Block } 2 \text { Charge } \\
& =\$ 20.80+\$ 2,794.31=\$ 2,815.11
\end{aligned}
$$

\section{Other Charges and Fees}

The remaining charges are fixed account charges and sales tax. For the 4-inch water line, FFI pays $\$ 760.76 /$ month. The fire line fee for the fire suppressant system is $\$ 37.25 /$ month, and the storm drain fee is $\$ 57.32 /$ month. The West Virginia state sales tax is $6 \%$. This tax is applied to the bill's subtotal.

This analysis highlights how understanding a rate structure is key to understanding your utility bill. Individual block volumes and charges are not listed on the bills. To understand why the water usage and sewer disposal charges were $\$ 3,582.64$ and $\$ 2,815.11$, respectively, requires understanding the rate structure and additional time and effort. Twelve months of utility data for FFI's production facility are summarized in Table 6. 
Table 6: FFI Water Bill Data.

\begin{tabular}{|c|c|c|c|c|c|c|c|c|c|}
\hline Month & $\begin{array}{l}\text { Usage } \\
\text { (gal) }\end{array}$ & $\begin{array}{l}\text { Usage } \\
\text { Cost }\end{array}$ & $\begin{array}{l}\text { Sewer } \\
\text { (gal) }\end{array}$ & $\begin{array}{c}\text { Sewer } \\
\text { Cost }\end{array}$ & $\begin{array}{l}\text { Meter } \\
\text { Fee }\end{array}$ & $\begin{array}{c}\text { Fire Line } \\
\text { Fee }\end{array}$ & $\begin{array}{c}\text { Storm Drain } \\
\text { Fee }\end{array}$ & Tax & Total \\
\hline June & 490,110 & $\$ 3,354.35$ & 490,110 & $\$ 2,632.19$ & $\$ 760.76$ & $\$ 37.25$ & $\$ 57.32$ & $\$ 410.51$ & $\$ 7,252.38$ \\
\hline July & 482,360 & $\$ 3,302.60$ & 482,360 & $\$ 2,590.73$ & $\$ 760.76$ & $\$ 37.25$ & $\$ 57.32$ & $\$ 404.92$ & $\$ 7,153.58$ \\
\hline August & 524,300 & $\$ 3,582.64$ & 524,300 & $\$ 2,815.11$ & $\$ 760.76$ & $\$ 37.25$ & $\$ 57.32$ & $\$ 435.18$ & $\$ 7,688.26$ \\
\hline September & 452,900 & $\$ 3,105.90$ & 452,900 & $\$ 2,433.12$ & $\$ 760.76$ & $\$ 37.25$ & $\$ 57.32$ & $\$ 383.66$ & $\$ 6,778.01$ \\
\hline October & 332,010 & $\$ 2,298.72$ & 332,010 & $\$ 1,786.35$ & $\$ 760.76$ & $\$ 37.25$ & $\$ 57.32$ & $\$ 296.42$ & $\$ 5,236.83$ \\
\hline November & 328,703 & $\$ 2,276.64$ & 328,703 & $\$ 1,768.66$ & $\$ 760.76$ & $\$ 37.25$ & $\$ 57.32$ & $\$ 294.04$ & $\$ 5,194.67$ \\
\hline December & 339,037 & $\$ 2,345.64$ & 339,037 & $\$ 1,823.95$ & $\$ 760.76$ & $\$ 37.25$ & $\$ 57.32$ & $\$ 301.49$ & $\$ 5,326.41$ \\
\hline January & 324,983 & $\$ 2,251.80$ & 324,983 & $\$ 1,748.76$ & $\$ 760.76$ & $\$ 37.25$ & $\$ 57.32$ & $\$ 291.35$ & $\$ 5,147.24$ \\
\hline February & 319,610 & $\$ 2,215.92$ & 319,610 & $\$ 1,720.01$ & $\$ 760.76$ & $\$ 37.25$ & $\$ 57.32$ & $\$ 287.48$ & $\$ 5,078.74$ \\
\hline March & 360,323 & $\$ 2,487.77$ & 360,323 & $\$ 1,937.83$ & $\$ 760.76$ & $\$ 37.25$ & $\$ 57.32$ & $\$ 316.86$ & $\$ 5,597.78$ \\
\hline April & 477,710 & $\$ 3,271.56$ & 477,710 & $\$ 2,565.85$ & $\$ 760.76$ & $\$ 37.25$ & $\$ 57.32$ & $\$ 401.56$ & $\$ 7,094.30$ \\
\hline May & 472,647 & $\$ 3,237.75$ & 472,647 & $\$ 2,538.76$ & $\$ 760.76$ & $\$ 37.25$ & $\$ 57.32$ & $\$ 397.91$ & $\$ 7,029.75$ \\
\hline Annual & $4,904,693$ & $\$ 33,731.29$ & $4,904,693$ & $\$ 26,361.30$ & $\$ 9,129.12$ & $\$ 447.00$ & $\$ 687.84$ & $\$ 4,221.39$ & $\$ 74,577.95$ \\
\hline
\end{tabular}




\subsection{Opportunities for Savings}

The same analysis from the previous section was carried out on all fiscal year 2021 utility data for FFI. The following section uses the historical data to estimate some initial water-savings opportunities for FFI based on tracking and understanding their utility bills.

\section{Utility Tracking}

The data from Table 6 was used to make the chart in Figure 11. The consumption and sewer data show a clear increase in usage starting from June through September. This could correspond to an increase in production at the facility or be related to higher water loads from the hot summer weather. FFI should investigate whether their water load increases because of the weather or if the increase is solely due to production. Identifying trends like this can help FFI spot anomalies to save water and plan their water usage to save costs.

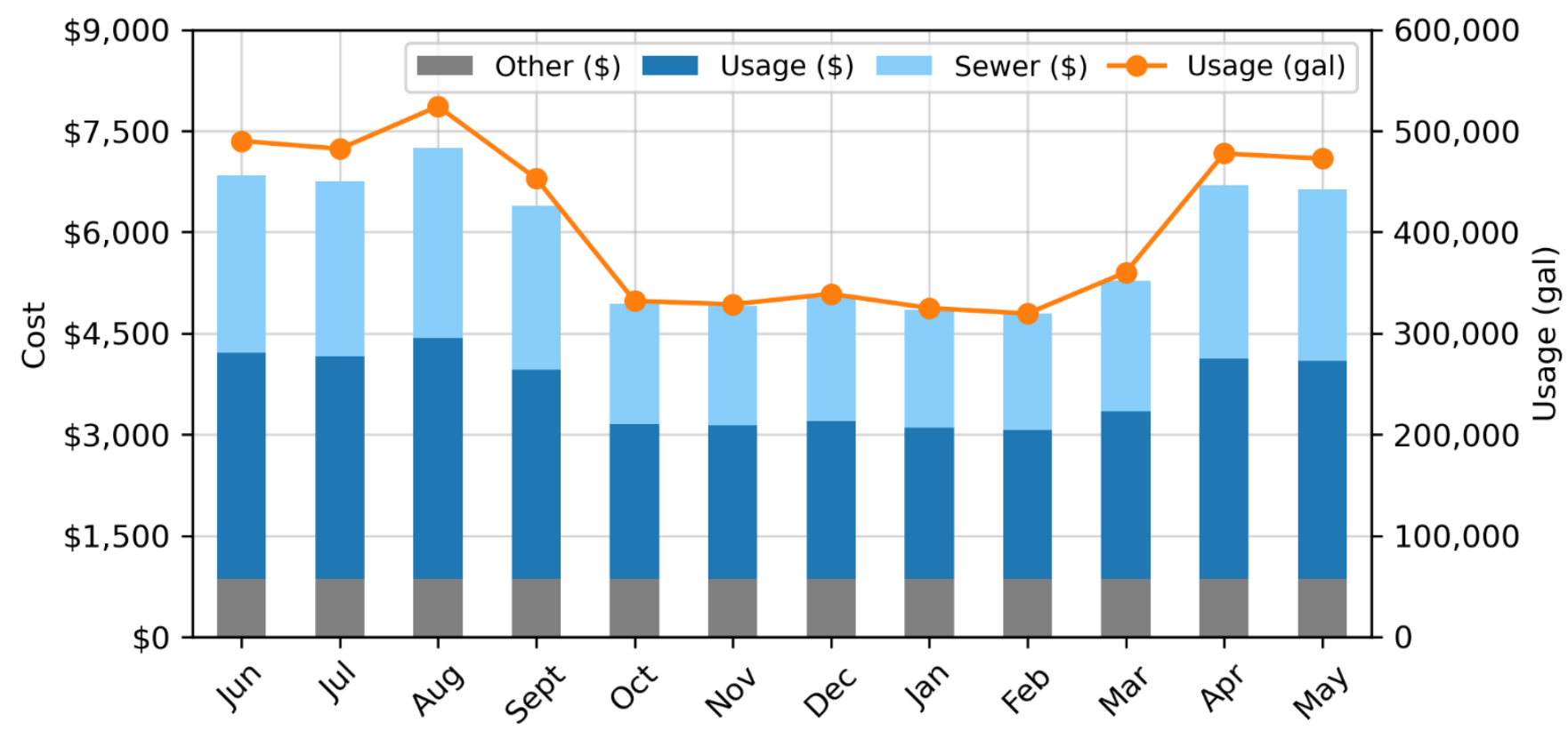

Figure 11: Annual Water Quantity and Cost.

Water bill anomalies that cannot be explained using production can signify several things. FFI could decide to check several prospects that may have led to the increase in the warmer months. One example is checking for a leak in the water system. FFI has scheduled maintenance days every month, and during one of these, they halt all water use. Using the flow indicator on their meter, they can investigate a possible leak. FFI could also investigate spikes due to weather changes by checking for non-process water use that is seasonally dependent. Examples include increased cleaning water caused by seasonal power washing or increased water demand because of landscaping needs. The increase should be investigated until a cause is found and can explain the demand fluctuations. Once an explanation is found, $\mathrm{FFI}$ should decide on corrective actions to reduce usage if possible. 


\section{Installing a Sewer Meter}

While conducting a water balance, FFI discovered that a high percentage of the incoming water is injected into the product. By using the PWPEx tool, facility personnel estimate that 35\% (roughly 1,716,642 gallons) of the incoming water is consumed and thus does not get discharged into the municipal sewer. The reduction in billed sewer volume will lead to direct sewer charges and avoided tax fees. By implementing a sewer meter, the facility could stand to save over $\$ 9,700$ annually based on fiscal year 2020-2021 data.

$$
\begin{gathered}
\text { Sewer Charge Savings }=\text { Annual Sewer Volume } \times \text { Sewer Charge } \times 35 \% \text { Sewer Savings } \\
=4,904,693 \times \$ 0.00535 \times 0.35=\$ 9,184.04 \\
\text { Avoided Sales Tax }=\text { Sewer Charge Savings } \times 6 \% \text { Tax Rate } \\
=\$ 9,184.04 \times 0.06=\$ 551.04 \\
\text { Total Savings from Sewer Meter }=\text { Sewer Charge Savings }+ \text { Avoided Sales Tax } \\
=\$ 9,184.04+\$ 551.04=\$ 9,735.08
\end{gathered}
$$

\section{Sales Tax Exemption}

The bill in Figure 10Figure 10 lists a $6.00 \%$ sales tax for each of the months analyzed. West Virginia allows manufacturers to claim a state sales tax exemption without a predominant use study. If FFI claims the exemption, they could save around \$4,200 annually based on fiscal year 2020-2021 data!

$$
\begin{aligned}
\text { Sales Tax Savings } & =\text { Sales }_{\text {Tax }} \text { Jan } \\
& =\$ 4,221.39
\end{aligned}
$$

\subsection{Summary}

Altogether, the preliminary analysis of FFI's utility bill data in this section has identified more than $\$ 13,000$ in utility savings. Although these projects are purely cost-savings opportunities, the potential to identify water usage savings also exists. Hopefully this example has illustrated how understanding and tracking your water bills can help your company save energy and money. Please contact your TAM or the Better Plants program if you have additional questions or would like help analyzing your utility bills. 


\section{Appendix A: Bibliography}

Centers for Disease Control and Prevention. Drinking Water, "Water Treatment," https://www.cdc.gov/healthywater/drinking/public/water_treatment.html.

Dieter, C. A., Maupin, M. A., Caldwell, R. R., Harris, M. A., Ivahnenko, T. I., Lovelace, J. K., Barber, N. L., and Linsey, K. S., Estimated Use of Water in the United States in 2015, US Geological Survey Circular 1441, 65 p., 2018, https://doi.org/10.3133/cir1441.

Price, C., Nimbalkar, S., and Wenning, T., Energy Intensity Baselining and Tracking Guidance (United States: Oak Ridge National Laboratory, Oak Ridge, TN, August 22, 2020), https://www.osti.gov/biblio/1649123.

Prigge J., "Ideas for using the true cost of water in sustainability strategy" March 22, 2019, https://www.greenbiz.com/article/ideas-using-true-cost-water-sustainability-strategy.

Rao, P., Developing a Corporate Water Management Strategy for Manufacturers (United States: Lawrence Berkeley National Laboratory, Berkeley, CA, April 2016), https://betterbuildingssolutioncenter.energy.gov/resources/corporate-water-management-strategymanufacturers

SM Engineering Co., "State Sales Tax Exemptions for Manufacturers," June 20, 2014, https://www.smeng.com/manufacturing-sales-tax-exemptions/.

Smart Home Water Guide, "How to Read your Water Meter," https://www.smarthomewaterguide.org/how-toread-your-water-meter.

US Department of Energy, Office of Energy Efficiency \& Renewable Energy, "Plant Water Profiler Tool-Excel, Version 1.0 (PWPEx v1.0)," https://www.energy.gov/eere/amo/plant-water-profiler-tool-excel-version-10pwpex-v10.

US Environmental Protection Agency. "Information about Public Water Systems," https://www.epa.gov/dwreginfo/information-about-public-water-systems.

US Environmental Protection Agency. "Safe Drinking Water Act (SDWA) Compliance Monitoring," https://www.epa.gov/compliance/safe-drinking-water-act-sdwa-compliance-monitoring.

US Environmental Protection Agency. "Summary of the Safe Drinking Water Act," https://www.epa.gov/lawsregulations/summary-safe-drinking-water-act.

US Environmental Protection Agency. "Understanding Your Water Bill," https://www.epa.gov/watersense/understanding-your-water-bill. 

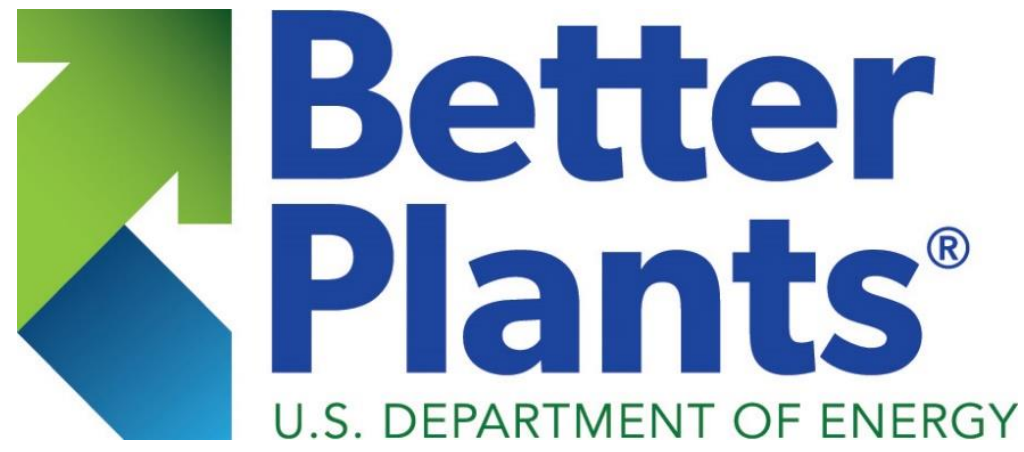